\begin{tabular}{|l|l|l|l|l|}
\hline $\begin{array}{l}\text { Cuadernos de Investigación Geográfica } \\
\text { Geographical Research Letters }\end{array}$ & 2019 & N$^{\circ} 45(2)$ & pp. 441-468 & eISSN 1697-9540 \\
\hline
\end{tabular}

\title{
CLEARING VS. BURNING FOR RESTORING PYRENEAN GRASSLANDS AFTER SHRUB ENCROACHMENT
}

\author{
C.L. ALADOS ${ }^{1}$, H. SAIZ ${ }^{1,2}$, P. NUCHE ${ }^{1}$, M. GARTZIA ${ }^{1}$, \\ B. KOMAC ${ }^{1,3}$, Á. DE FRUTOS ${ }^{1}$, Y. PUEYO ${ }^{1}$ \\ ${ }^{1}$ Instituto Pirenaico de Ecología (CSIC), Avda Montañana 1005, P. O. Box 13034, 50080 Zaragoza, Spain. \\ ${ }^{2}$ Departamento de Biología y Geología, Física y Química Inorgánica, \\ Universidad Rey Juan Carlos, 28933 Móstoles, Spain. \\ ${ }^{3}$ Centre d'Estudis de la Neu i la Muntanya d'Andorra, Institut d'Estudis Andorrans (CENMA - IEA). \\ Avinguda Rocafort 21-23, AD600 Sant Julià de Lòria, Principat d'Andorra.
}

\begin{abstract}
Anthropogenic activities have modified vegetation on subalpine belts for a long time, lowering the treeline ecotone and influencing the landscape mainly through grazing and fire. The abandonment of these traditional land use practices during the last decades and global warming are contributing largely to the colonization of woody species in subalpine grasslands, causing irreversible changes in ecosystem functioning. A variety of management strategies requiring the use of fire and/or clear-cutting are carried out to prevent the expansion of highly encroaching shrubs and improve the conservation status of subhumid high-productive grasslands ecosystems. However, it is still poorly understood how different management strategies affect the recovery of subalpine grasslands, which is influenced concurrently by the vegetation community involved. In this study we used field experiments to test the impact of management treatments on soil properties and vegetation responses in subalpine Bromion erecti grassland communities colonized by the pyrophyte shrub Echinospartum horridum (Vahl) Rothm. on the southern Pyrenees. Vegetation was monitored for 5 years in E. horridum plots (two plots per treatment) where the vegetation was removed by prescribed fire (Burnt treatment) or by mechanical removal (Clear-cut treatment). Undisturbed E. horridum plots were used as a control (C-Erizón) for shrub removal treatments and a Bromion erecti grassland community regularly grazed (C-Grass) was used as a control for subalpine grassland. Clear-cut treatment of E. horridum community was more effective to control $\mathrm{E}$. horridum colonization than Burnt treatment and contributed to a higher extent to recover original grassland vegetation, because E. horridum seedling performed worse (lower germination rates) and plant species were more similar to the original grassland (legumes, non-legume forbs, and grasses). Shrubs and sub-shrubs cover in Burnt areas increased faster than in Clear-cut areas during the 5 years following the treatment, although it did not reach the level of C-Erizon. Species richness and diversity increased in comparison with C-Erizón in both treatments, but they were
\end{abstract}


significantly lower than those in the C-Grass. Network connectivity was larger in well preserved grasslands, i.e, $C$-Grass, than in any other treatments, mainly dominated by negative plant-plant association. Soils nutrients declined in Burnt sites 4 years after the fire treatment and no difference was observed between Clear-cut and C-Erizón sites, although they did not reach the soil fertility values of $C$-Grass in terms of organic matter and $C / N$ ratio. This study showed that grazing favors plant diversity and community complexity in subalpine grasslands. It also demonstrated that clearing is a better strategy than burning to restore grasslands after shrub encroachment because burning entails deeper soil degradation and faster recovering of the pyrophyte shrub, E. horridum.

\section{Desbroces frente a quemas para restaurar los pastos pirenaicos tras la expan- sion del matorral}

RESUMEN. Las actividades antrópicas han modificado la vegetación en los cinturones subalpinos durante mucho tiempo, disminuyendo el ecotono del limite del bosque e influyendo en el paisaje principalmente a través del pastoreo y el fuego. El abandono de estas prácticas tradicionales de uso de la tierra ocurrido durante las últimas décadas y el calentamiento global están contribuyendo en gran medida a la colonización de especies leñosas en pastos subalpinos, causando cambios irreversibles en el funcionamiento de los ecosistemas. Actualmente se están llevando a cabo diferentes estrategias de gestión que requieren el uso de fuego y / o desbroce para prevenir la expansión de arbustos altamente invasores y mejorar el estado de conservación de los ecosistemas de pastizales subhúmedos de alta productividad. Sin embargo, todavía desconocemos cómo las diferentes estrategias de gestión afectan la recuperación de los pastos subalpinos, la cual depende a su vez de la comunidad vegetal involucrada. En este estudio, utilizamos experimentos de campo para evaluar el impacto de los tratamientos de manejo sobre las propiedades del suelo y las respuestas de la vegetación en las comunidades de pastos subalpinos de Bromion erecti colonizados por el arbusto pirófito Echinospartum horridum (Vahl) Rothm. en el sur de los Pirineos. La vegetación fue monitoreada por 5 años en parcelas de E. horridum (dos parcelas por tratamiento) donde la vegetación fue eliminada por fuego prescrito (tratamiento de Quemado) o por desbroce mecánico (tratamiento de Desbroce). Se utilizaron parcelas no perturbadas de E. horridum como control (C-Erizón) para los tratamientos de eliminación de arbustos y se usó una comunidad de pastos Bromion erecti regularmente pastada (C-Grass) como control de pastos subalpinos. El tratamiento de Desbroce de la comunidad de E. horridum fue más eficaz para controlar la colonización de E. horridum que el tratamiento de Quemado y contribuyó en mayor medida a recuperar la vegetación original de pastizales, porque las plántulas de E. horridum tuvieron un peor rendimiento (menores tasas de germinación) y las especies de plantas fueron más similar al pasto original (leguminosas, hierbas no leguminosas y pastos). La cobertura de arbustos y sub-arbustos en las áreas quemadas aumentó más rápido que en las áreas desbrozadas durante los 5 años posteriores al tratamiento, aunque no alcanzó el nivel de C-Erizón. La riqueza 
de especies y la diversidad aumentaron en comparación con C-Erizón en ambos tratamientos, pero fueron significativamente más bajos que los de C-Grass. La conectividad de la red fue mayor en los pastos bien conservados, es decir, C-Grass, que en cualquier otro tratamiento, principalmente dominado por la asociación negativa planta-planta. Los nutrientes del suelo disminuyeron en sitios quemados 4 años después del tratamiento con fuego y no se observaron diferencias entre los sitios desbrozados y C-Erizón, aunque no alcanzaron los valores de fertilidad del suelo de C-Grass en términos de materia orgánica y relación $C / N$. Este estudio mostró que el pastoreo favorece la diversidad de plantas y la complejidad de la comunidad en los pastos subalpinos. También demostró que el desbroce es mejor estrategia que la quema para restaurar los pastos tras la invasión de los arbustos porque la quema implica una degradación más profunda del suelo y una recuperación más rápida del arbusto pirófito, E. horridum.

Keywords: subalpine vegetation, diversity, Echinospartum horridum, grassland restoration, plant-plant association, soil fertility.

Palabras clave: vegetación subalpina, diversidad, Echinospartum horridum, restauración de pastos, asociación planta-planta, fertilidad del suelo.

Received: 15 March 2018

Accepted: 5 July 2018

*Corresponding author: Concepción L. Alados, Instituto Pirenaico de Ecología (CSIC), Avda. Montañana 1005, P. O. Box 13.034, 50080 Zaragoza, Spain. E-mail address: alados@ipe.csic.es

\section{Introduction}

The subhumid grassland communities in mountain regions are shifting from productive grasslands to high competitive shrubland communities as reported in several alpine and subalpine zones (Anthelme et al., 2002; Tasser and Tappeiner, 2002; Gellrich et al., 2007; Gartzia et al.,2014). This process commonly called shrub encroachment is rapidly increasing as a result of climate and land use change (Guisan and Theurillat, 2000; Gehrig-Fasel et al., 2007). Shrub encroachment has profound effects on natural ecosystems: produces irreversible changes in ecosystem functioning (Knapp et al., 2008) and services (Metzger et al., 2006), modifies landscape net primary production patterns (Moreno-de-las-Heras et al., 2015), reduces biodiversity (Price and Morgan, 2008) and changes soil and vegetation properties towards an increase of resistance to runoff related erosion processes, but a decrease of slope stability against shallow landslides (Caviezel et al., 2014). However, this vegetation shift is not constant across mountain regions and will depend upon different factors, such as land management history (Milchunas et al., 1988), climate conditions (Sankaran et al., 2005), or vegetation structure (Theurillat and Guisan, 2001). 
There is large evidence of the influence of climate change on plant distribution in European alpine mountain areas (Guisan and Theurillat, 2000), where the growingseason temperature is the primary factor affecting the treeline ecotone (Körner and Paulsen, 2004). Nevertheless, different studies reported little changes in community composition in subalpine grasslands in response to warming (Price and Waser, 2000; Vittoz et al., 2009) because the invasion of new herbaceous species may be hampered by the density of local ones (e.g. Poaceae and Cyperaceae with high longevity), resulting in limited species replacement (Theurillat and Guisan, 2001) and suggesting the importance of biotic interactions as drivers of assemblage processes in these communities. On the other hand, several other non-climatic factors such as anthropogenic management are also reported to influence plant community changes in the European alpine mountains (Gehrig-Fasel et al., 2007). According to Körner's hypothesis (Körner, 2005), future vegetation changes in mountain areas will be influenced more by anthropogenic management than by climate. Overall, anthropogenic activities have modified vegetation for a long time (Tinner and Theurillat, 2003). Grazing and fire have lowered the treeline ecotone and influenced species distribution in subalpine belts (Olofsson et al., 2009; Speed et al., 2012). Grazing by vertebrate herbivores reduces the impact of warming on plant communities in alpine ecosystems, maintaining the abundance of graminoids in contrast to the increase of woody vegetation in areas with no grazing (Post and Pedersen, 2008; Speed et al., 2012). For example, large herbivores such as reindeer enhance nutrient cycling and productivity, reduce shrub cover and promote graminoid vegetation in the Arctic tundra (van der Wal, 2006).

Socioeconomic changes in Europe are leading to emigration from rural areas to industrialized cities, causing substantial depopulation (Romano, 1995; André, 1998; Ayuda and Pinilla, 2002) and land abandonment of rural mountain areas (MacDonald et al., 2000; Gehrig-Fasel et al., 2007). The abandonment of pasturelands leads to a reduction of grazing and, consequently, the recolonization of subalpine grasslands by trees and shrubs (Vittoz et al., 2008; Peringer et al., 2013), which is further encouraged by fire suppression practices (Moreira et al., 2001; Pausas et al., 2008). Land use changes are considered the main driver in terrestrial ecosystems, whereas biodiversity of grassland and mountain ecosystems is expected to be especially sensitive to these changes (Sala et al., 2000).

Many of the European grassland ecosystems with high conservation value are threatened by the change of those land uses that created and maintained them over the time (WallisDeVries et al., 2002; Öckinger et al., 2006; Veen et al., 2009). Most rangelands are considered fire-dependent ecosystems, where historical fire regimen maintained under control woodland expansion (Limb et al., 2016). Prescribed fire has been used as a management tool in rangeland ecosystems, for regenerating pastures, because fire can promote forage production, quality and palatability, and also opens up new foraging areas where canopy closure by shrubs obstructed the access to grasslands areas (Hobbs and Spowart, 1984; Cook et al., 1994; Cubit, 1996; Collins et al., 1998; Fernandes et al., 2013; Clark et al., 2016; Santín and Doerr, 2016). Although there is large knowledge on the effects of fire on forests (Pausas et al., 2008; Fernandes et al., 2013; Santín and Doerr, 2016), the response 
of ecosystems to fire is still not fully understood because it depends on the spatial and temporal scale, the historical fire regime, and presence of other environmental stressors (e.g. drought and grazing) (Limb et al., 2016). Moreover, the influence of fire on soil fertility showed contradictory results. Some authors reported soil nutrient decreases after prescribed fire events (Martínez-Mena et al., 2001; San Emeterio et al., 2016; Nuche et al., 2018), while others reported neutral or even positive effects on soil nutrients (Fernandes et al., 2013).

In recent time, clear-cut has been proposed as a management practice to control shrub cover expansion (Lasanta et al., 2009) and improve plant diversity (Collins et al., 1998), although little information exists concerning the effect of clearing on grasslands restoration (Pittarello et al., 2016). Clear-cut is an appropriate management practice because it contributes to the recovery of herbaceous coverage and is less aggressive than fire (Fernández-Santos et al., 1992), but it requires being along with active grazing (Álvarez-Martínez et al., 2016; Kirkpatrick et al., 2016) to control shrub expansion.

Optimal management of pastures requires the use of fire and/or clear-cutting, particularly for the conservation of grasslands in subhumid high productive ecosystems (Sankaran et al., 2005). However, the optimal strategy that guarantees the sustainability of alpine and subalpine grasslands is still not known. The response of the plant community to a given management treatment is expected to depend on the characteristics of dominant species and on the disturbance regimen in the area (Pausas et al., 2008). Most of the fire-prone communities are rich in shrubs and sub-shrubs able to resprout after a fire event, and majority of non-resprouting species growing in those ecosystems are post-fire recruiters (i.e., plants whose seeds are stimulated by the fire heat (Paula and Pausas, 2008), which increase their population size after a fire event (Vilà et al., 2008). Different researchers have documented changes in resprouting capacity after experimental recurrent clipping (Canadell and López-Soria, 1998; Paula and Ojeda, 2006). On the other hand, biotic interactions between plant species can play an important role in post-fire successional processes. For example, after fire events shrub resprouter species can enhance the opportunities for seeding establishment (Raffaele and Veblen, 1998; Pausas and Keelay, 2014), while grasses can become more competitive (Melgoza et al., 1990; Canals et al., 2014). Finally, grazing interferes with fire/clear-cut. For instance, grazing after burning increases plant diversity even in periodically burnt grassland (Collins et al., 1998). Therefore, grasslands restoration needs to evaluate rangeland management practices and incorporate temporal dynamics to support predictive inferences.

We focused this study in Pyrenees subalpine grasslands, where the expansion of woody species is a serious threat to grassland conservation (Komac et al., 2011a; Gartzia et al., 2014; Nadal-Romero et al., 2018) and human activities have played a key role in maintaining these ecosystems for centuries (Montserrat and Fillat, 1990). Echinospartum horridum (Vahl) Rothm. (Erizón) is a strictly calcicolous chamaephyte, thorny cushion, endemic of the Pyrenees, which occurs mainly on south facing slopes (Benito Alonso, 2006). It is among the most aggressive species encroaching Pyrenean grasslands and it 
is spreading rapidly (Komac et al., 2011a). Empirical studies reported increased seed germination and seedling survival of $E$. horridum after burning and in less extent under clearing treatment (Nuche et al., 2018). Thus, it is of major importance to understand the dynamics of this species if optimal management practices are to be applied in the Pyrenees.

In this study we addressed the effects of two common management practices used to control shrub encroachment in grassland plant communities of Spanish Pyrenees (i.e., burning and clear-cutting). To do that, we run a 5-year manipulative experiment to monitor changes in vegetation structure and soil properties after prescribed fire and clear-cut events, comparing them against two control communities: the original Bromion erecti grasslands and the shrub encroached E. horridum community. Specifically, we (1) investigated the effect of burnt and clear-cut treatments in the vegetation structure and soil properties of the E. horridum community that invaded subalpine grassland; and (2) evaluated the suitability of the treatments to recover the original productive grasslands.

We predicted that (H1) E. horridum, as a pyrophytic species, would be more competitive and would recover faster after prescribed fire than after clear-cut, while the latter treatment would promote a faster recovery of grasses and forbs species by more efficient removal of the competitor E. horridum. We also expected (H2) a more similar vegetation composition to the original Bromion erecti grasslands in the clear-cut experiment than in the burnt treatment. We also predict that $(\mathrm{H} 3)$ soil nutrient contents would be affected differently by rangeland management practices, such as burning and clear-cutting. Burning was expected to be associated with higher loss of soil nutrients and slower recovery of soil properties than clear-cutting.

\section{Materials and Methods}

\subsection{Study Area}

The study was conducted in the Central Pyrenees, at the Ordesa and Monte Perdido National Park and its peripheral zone, in northern Spain. The study included two locations with prescribed fire and clear-cutting areas: Torla $\left(42^{\circ} 38^{\prime} 34^{\prime}\right.$ ' $\mathrm{N}, 0^{\circ} 07^{\prime} 36^{\prime \prime} \mathrm{W}$, $1720 \mathrm{~m}$ a.s.1.) and Tella (42 $36^{\prime}$ '09' $\mathrm{N}, 0^{\circ} 10^{\prime} 53^{\prime}$ 'W, $1960 \mathrm{~m}$ a.s.l.). The Bromion erecti regularly grazed grassland communities (C-Grass) used as a control for subalpine grassland were located in Góriz (42 $36^{\prime} 25^{\prime}$ 'N, $0^{\circ} 01^{\prime}$ 03' ' E, $1904 \mathrm{~m}$ a.s.l.) and Sesa (42 $35^{\circ} 56^{\prime}$ 'N, $0^{\circ} 04^{\prime} 14^{\prime}$ ' E, $1735 \mathrm{~m}$ a.s.l.) (Fig. 1). The average mean minimum and maximum temperature at the nearest meteorological station between 1982 and 2012 (Refugio de Góriz at $2200 \mathrm{~m}$ a.s.1. $42^{\circ} 39^{\prime} 48^{\prime}{ }^{\prime} \mathrm{N}, 0^{\circ} 00^{\prime}$ '54' 'E) was 1.5 and $8.7^{\circ} \mathrm{C}$ and the average annual precipitation was $1688 \mathrm{~mm}$. The average slope in the study area ranged from approximately $10^{\circ}$ to $30^{\circ}$.

Vegetation was originally a subalpine Bromion erecti grassland community over calcareous soil substrate dominated by herbaceous species such as Bromus erectus Huds., Festuca rubra L. or Plantago lanceolata L., and species with a high fodder value, such as Trifolium and Medicago spp. These grasslands have been colonized by E. horridum, 
a chamaephyte that reproduces asexually through clonal propagation of decumbent branches, forming dense monospecific patches (cover $>90 \%$ of the soil surface).

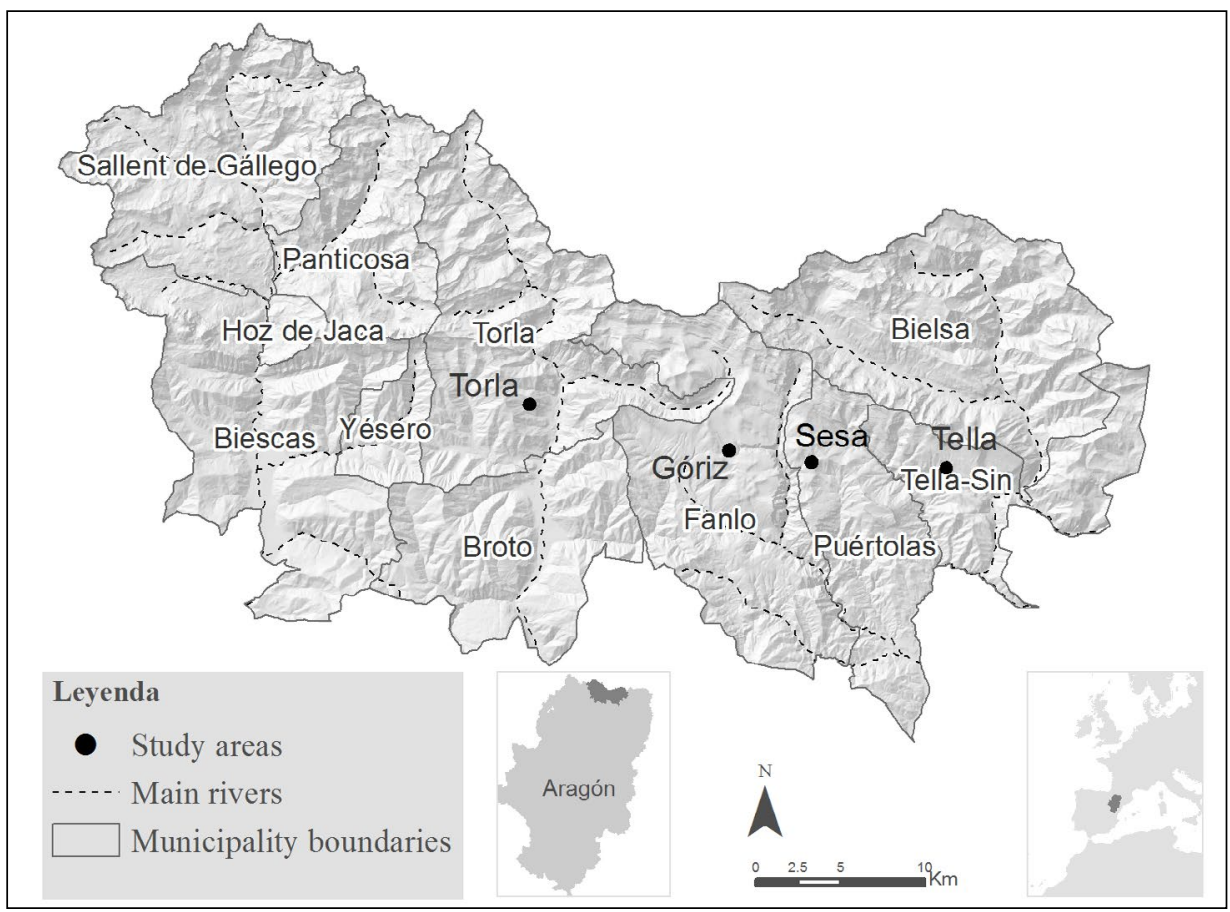

Figure 1. Study area and location of field sites.

In 2008 and 2010 autumn, E. horridum patches of 7.7 and 11.8 ha were burnt in Torla and Tella, respectively (Burnt treatment). Clear-cut treatment was established by clipping the aerial biomass of E. horridum: $100 \mathrm{~m}^{2}$ were clipped in Torla in 2008 autumn and 1.25 ha in Tella in April 2012 (Fig. 2). Clipped material was left in the soil and it was homogeneously distributed to simulate the homogeneity of the E. horridum cover. We selected areas dominated by E. horridum located near the study sites (around 200-400 m away) as a control treatment (C-Erizón), that we sampled the first year of treatment establishment. We used data from pastures located in Góriz and Sesa sampled in 2004 and 2005, as controls of well-preserved Bromion erecti grassland community that is not invaded by E. horridum (C-Grass). Those grasslands are very resilient to environmental pressure as it is demonstrated after two decades of herbivore exclusion, which did not trigger large changes in community structure and diversity losses (Pardo et al., 2015). After the application of the treatments, sites were grazed yearly by sheep and cattle from early June to late September. Grazing pressure ranged between 0.7-0.8 livestock units $(\mathrm{LU}) / \mathrm{ha}(1$ sheep $=0.125 \mathrm{LU}$ and $1 \mathrm{cow}=0.80 \mathrm{LU})$ during the summer grazing period (June to September). We surveyed the vegetation composition in control treatments once because plant communities were stable during the study period. However, soil properties were surveyed both the first and fourth year after the treatment in the control C-Erizón. 


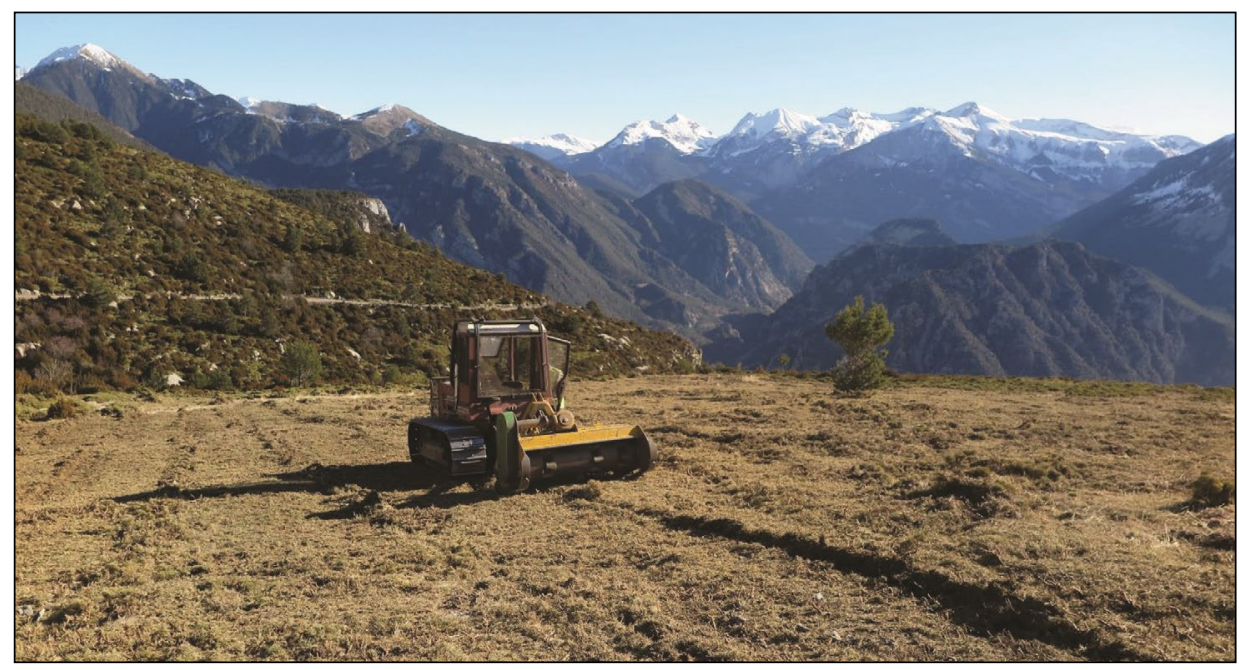

Figure 2. Brush-cutting of Echinospartum horridum in Tella mountain.

\subsection{Data collection and analysis}

At all sites vegetation was monitored at the peak of the vegetation growing season. We used the Point-Intercept Method (Goodall, 1952) to record the presence of individual plants (at $10-\mathrm{cm}$ intervals) along sixty $210-\mathrm{m}$ transects; 6 per Burnt treatment and year (33 in total, 18 in Torla during 6 years and 15 in Tella during 5 years), 3 transects per Clear-cut treatment and year (15 in total in Tella during 5 years period), 6 transects per control (12 in total, 6 per C-Erizón and 6 per C-Grass). The transects were marked with permanent labels every $50 \mathrm{~m}$ for the repeated measures. We identified a total of 234 different plant species, comprising 28 woody species, 18 legumes (excluding E. horridum), 155 nonlegume forbs and 33 grass species. The relative vegetation cover was calculated for each functional group as the number of count of individual plants included in each functional group divided by the total number of individual plants present along each $210-\mathrm{m}$ transect.

The reproductive capacity of E. horridum was evaluated by recording the number of seedlings that germinated annually and their subsequent yearly survival from 1 $\mathrm{m}^{2}$ permanent plots (20 per treatment and year). Data were collected in mid-May of each year. Germination was collected during 5 years after treatment and survival was only recorded the second and third years after treatment because of the difficulty to differentiate between individual seedlings for longer periods.

Species diversity was estimated for each transect using the Evenness index, which was calculated as the Shannon Index divided by the natural logarithm of the species number.

Shannon Index, $H^{\prime}$ (Shannon, 1948), $H^{\prime}=\sum_{i=1}^{N} p_{i} \ln \frac{1}{p_{i}}$ 
where $p_{\mathrm{i}}$ is the probability of the frequency of the $i$-th species. In our study, $p_{\mathrm{i}}$ was the relative cover of species $i$ on a 210-m transect.

To evaluate the role of biotic interactions structuring the community, we measured the spatial pattern between pairs of species in the plant community. Although inferring biotic interactions from spatial patterns is not exempt of criticisms (Wiegand et al., 2012; ChacónLabella et al., 2017), local spatial association is a common method to estimate biotic interactions in plant communities (Valiente-Banuet and Verdú, 2008; Cavieres and Badano, 2009). We calculated the number of positive and negative spatial associations within the matrices of co-occurring species on each transect. Specifically, we compared the observed number of co-occurrences considering the upper and lower limits of the $95 \%$ confidence intervals of the Poisson distribution (Saiz and Alados, 2012). Two species were said to co-occur if they were present at the same sampling point on a given transect. Recurrent or rare local co-occurrences were assumed to reflect plant interactions (i.e., facilitation or competition), instead of merely plants that share habitat requirements (Saiz and Alados, 2012; Soliveres and Maestre, 2014). We calculated the number of positive, $\mathrm{K}^{+}$, and negative, $\mathrm{K}^{-}$, associations between pairs of species on each transect as the number of pairs of species that presented significantly more or less co-occurrences than expected by the confidence interval. We assumed that two species that co-occurred more often than expected benefited from the association, and interference was inferred if two species segregated more than expected (Tilman and Kareiva, 1997; Tirado and Pugnaire, 2005). We calculated the dominant spatial pattern as the ratio of positive to negative associations $\left(\mathrm{K}^{+}-\mathrm{K}^{-}\right) /\left(\mathrm{K}^{+}+\right.$ $\mathrm{K}^{-}$), which is a symmetrical estimate around zero that is used widely in ecology (Armas et $a l ., 2004)$. This ratio ranges from -1 (dominance of spatial segregation) to 1 (dominance of spatial aggregation). Mechanisms and consequences of the overall balance of interactions are easier to identify if the competition and facilitation components are evaluated individually (Callaway and Walker, 1997; Michalet et al., 2014). To control the influence of species richness on association frequency, we divided the number of positive $\left(\mathrm{K}^{+}\right)$and negative $\left(\mathrm{K}^{*}\right)$ spatial associations by the number of species $(\mathrm{S})$ in the transect, referred as the density of positive $\left(\mathrm{D}^{+}\right)$and negative (D) associations, respectively. We also estimated network connectivity $(\mathrm{NC})$ as the number of significant spatial associations $(\mathrm{K})$ divided by the number of all potential spatial associations $(\mathrm{NC}=2 \mathrm{~K} / \mathrm{S}(\mathrm{S}-1))$.

Four soil samples were collected from the upper $15 \mathrm{~cm}$ of soil along each of the three 210-m transects associated to each combination of treatment (Burnt, Clear-cut, C-Erizón) and location (Torla and Tella) on the first and fourth year after treatment (total of 72 soil samples). Sampling was undertaken in 2009 and 2012 in Torla, and in 2012 and 2015 in Tella. In addition, 12 soil samples were collected in Góriz and Sesa in 2017.

Soil samples were dried in the laboratory and passed through a $2-\mathrm{mm}$ sieve. Soil $\mathrm{pH}$, organic matter content $(\mathrm{OM})$, carbon $(\% \mathrm{C})$, nitrogen $(\% \mathrm{~N})$, and the $\mathrm{C} / \mathrm{N}$ relationship were quantified at each sample. After soil samples were polished, total $\mathrm{C}$ and $\mathrm{N}$ were quantified using an elemental analyzer Variomax Elementar (DUMAS procedure). Organic carbon content was quantified using dichromate (Heanes, 1984). Organic matter content was calculated multiplying \% organic Carbon by the Van Bemmelen Factor 1.724 (Heanes, 1984), which assumes that OM is 58\% organic C. 


\subsection{Statistical analyses}

To analyze management treatment effect after 5 years (Burnt, Clear-cut) in comparison with control (C-Erizón) and with a well-preserved subalpine grassland community (C-Grass) we conducted a Linear Model (LM). The dependent variables were: vegetation spatial associations (network Connectivity (NC), density of negative associations (D), density of positive association $\left(\mathrm{D}^{+}\right)$, ratio of positive and negative spatial associations $\left(\left(\mathrm{K}^{+}\right.\right.$ - $\left.\mathrm{K}^{-}\right) /\left(\mathrm{K}^{+}+\mathrm{K}^{-}\right)$), Bare soil and E. horridum cover, and Evenness. Percentage values were subjected to angular transformation to achieve the normality of the data.

To evaluate the E. horridum reproductive capacity after treatment, we performed Generalized Linear Mixed Model (GLMM) with Poisson distribution errors. The number of germinated seeds per square meter was the dependent variable, treatment (C-Erizón, Clear-cut and Burnt) was the fixed factor, plots nested within locations were included as a random effect factor and year as repeated measure. C-Grass treatment was not included as E. horridum is not present in C-Grass.

The survival capacity of emerged seedlings one year after germination was evaluated by GLMM with a binomial distribution (survive/dead), treatment (Clear-cut and Burnt) was the fixed factor, proportion of seedlings that survived one year after treatment was the response variable, plots nested within locations were included as random effect factor, and year as repeated measure. C-Erizón was not included as treatment effect factor because the germinated seeds were almost neglected, and consequently the subsequent survival was not calculated.

To test the change of vegetation structure with time after the treatment (Burnt and Clear-cut) we used a Lineal Mixed Model (LMM) for each vegetation variable individually. Plots were included as a random factor. The controls C-Erizón and C-Grass were not included as treatment effects because these vegetation communities were stable during the study period. The dependent variables were vegetation spatial associations (network Connectivity (NC), density of negative associations (D-), density of positive association $\left(\mathrm{D}^{+}\right)$, and ratio of positive to negative associations $\left(\left(\mathrm{K}^{+}-\mathrm{K}^{-}\right) /\left(\mathrm{K}^{+}+\mathrm{K}^{-}\right)\right)$, and vegetation composition (Bare soil and E. horridum cover and Evenness). Percentage values were subjected to angular transformation to achieve normality.

To identify significant differences in the soil properties for each treatment, we also used a LMM with treatments (C-Erizón, Clear-cut and Burnt) as fixed factor and soil nutrients (nitrogen $(\% \mathrm{~N})$, carbon $(\% \mathrm{C})$, Carbon/Nitrogen ratio $(\mathrm{C} / \mathrm{N})$, organic matter $(\mathrm{MO})$, and $\mathrm{pH})$ in first and fourth year after treatment as response variables. Plots were nested with locations and included as a random effect factor. Data in percentages were arcsine transformed for normalization.

LMM and GLMM were performed using the lme function in the nlme library and glmer in the lme 4 of the $\mathrm{R}$ package respectively (Pinheiro et al., 2014). The analyses followed the protocol of Zuur et al. (2009). The optimal structure of the model was identified based on the lowest Akaike's Information Criterion (AIC). Residuals were tested for normality and homogeneity of variance following model validation protocol of Zuur et al (2009). Post-hoc pairwise comparisons between treatments were performed with Tukey HSD test for mixed models with multcomp package (Hothorn et al. 2008). All the statistical analyses were performed using R 3.2.2 (R Core Team, 2014). 


\section{Results}

3.1. Effects of Burnt and Clear-cut the $5^{\text {th }}$ year after the treatment on plant community structure in comparison with grassland community (C-Grass) and E. horridum community (C-Erizón)

Bare soil varied significantly with treatment effects (Table 1). Tukey test showed that after 5 years from the treatment, bare soil cover was significantly higher in Burnt and Clear-cut treatments than in both controls. Conversely, E. horridum cover was significantly higher in C-Erizón in comparison with C-Grass, Burnt and Clear-cut treatments. Burnt treatment had higher E. horridum cover (more than double) than Clearcut treatment. E. horridum was absent in C-Grass while C-Erizón had $69.51 \%$ of woody species cover; most of them were E. horridum (61.4\%). C-Grass had a high cover of herbaceous species, being $45.5 \%$ non-legume forbs, $40.6 \%$ grasses and $12.3 \%$ legumes. On the $5^{\text {th }}$ year after the Burnt and Clear-cut treatments, the relative cover of grasses and non-legume forbs increased. The abundance of woody species also increased, particularly E. horridum abundance was $34.8 \%$ and $15.1 \%$ five years after Burnt and Clear-cut treatments respectively. Comparisons between treatments revealed statistically significant differences in vegetation composition $\left(\mathrm{F}_{3,17}=126.51, \mathrm{P}<0.001\right.$, for woody, $\mathrm{F}_{3,17}=22.18, \mathrm{P}<0.001$ grass, $\mathrm{F}_{3,17}=53.98, \mathrm{P}<0.001$ legumes, and $\mathrm{F}_{3,17}=14.85, \mathrm{P}<0.001$ non-legume forbs species). The abundance of legumes, grasses and non-legume forbs was significantly higher in C-Grass than in Burnt and C-Erizón. Clear-cut treatment presented vegetation covers closer to $\mathrm{C}$-Grass than to the other two conditions, although Burnt treatment favored legumes rather than Clear-cut (Fig. 3).

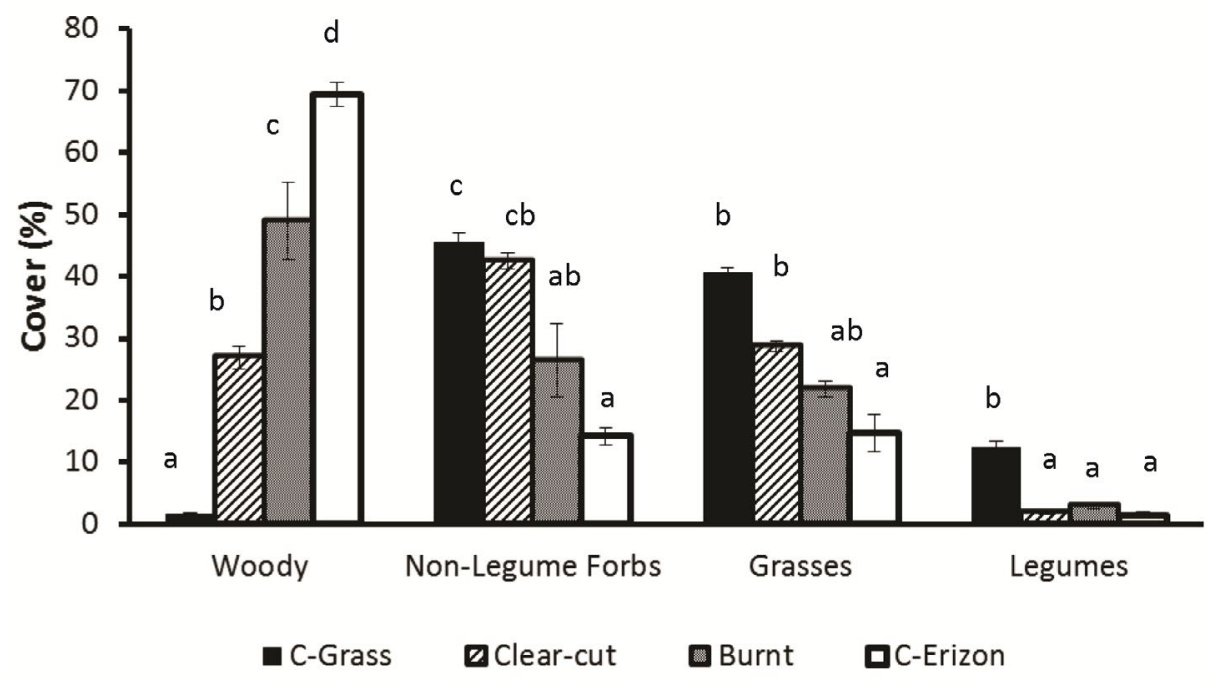

Figure 3. Bar graph representation of vegetation cover (woody, non-legume forbs, grasses, legumes) changes 5 years after the Burnt and Clear-cut treatments in comparison with controls (C-Grass and C-Erizón). Bars with different letters show significant differences between treatments $(P<0.05)$ as per Tukey test pairwise comparison. 
Species diversity (Evenness index) was significantly lower in C-Erizón in comparison with the other treatments (Table 1). Species richness was the largest in C-Grass. Clear-cut and Burnt treatments did not differ in species diversity or species richness on the $5^{\text {th }}$ year after the treatment.

Table 1. Vegetation cover (Bare soil and $\mathrm{E}$. horridum), plant community structure (Evenness, Richness) and plant-plant association network (Network Connectivity (NC), Density of negative association $\left(D^{-}\right)$, Density of positive association $\left(D^{+}\right)$, ratio of positive to negative association

(Ratio)) 5 year after the treatment (Burnt, Clear-cut) and controls (C-Erizón, C-Grass).

Differences between treatments were evaluated with linear model (one way ANOVA) and pairwise comparisons with Tukey test $* P<0.5$, ** $P<0.01$, *** $P<0.001$.

\begin{tabular}{|l|l|l|l|l|l|}
\hline $\begin{array}{c}\text { Variable } \\
\text { response }\end{array}$ & \multicolumn{1}{|c|}{$\begin{array}{c}\text { C-Grass } \\
\text { mean } \pm \text { se }\end{array}$} & \multicolumn{1}{c|}{$\begin{array}{c}\text { Burnt } \\
\text { mean } \pm \text { se }\end{array}$} & $\begin{array}{c}\text { Clear-cut } \\
\text { mean } \pm \text { se }\end{array}$ & $\begin{array}{c}\text { C-Erizón } \\
\text { mean } \pm \text { se }\end{array}$ & \multicolumn{1}{|c|}{ F3,17 } \\
\hline Baresoil & $7.08 \pm 1.30^{\mathrm{b}}$ & $17.37 \pm 4.11^{\mathrm{a}}$ & $18.27 \pm 2.76^{\mathrm{a}}$ & $2.09 \pm 0.52^{\mathrm{b}}$ & $12.85^{* * *}$ \\
\hline E.horridum & $0 \pm 0^{\mathrm{a}}$ & $49.05 \pm 8.80^{\mathrm{c}}$ & $18.21 \pm 2.25^{\mathrm{b}}$ & $86.17 \pm 1.79^{\mathrm{d}}$ & $111.88^{* * *}$ \\
\hline Evenness & $0.69 \pm 0.01^{\mathrm{a}}$ & $0.63 \pm 0.03^{\mathrm{a}}$ & $0.68 \pm 0.01^{\mathrm{a}}$ & $0.43 \pm 0.03^{\mathrm{b}}$ & $18.36^{* * *}$ \\
\hline Richness & $64.17 \pm 2.02^{\mathrm{a}}$ & $58.0 \pm 4.13^{\mathrm{ab}}$ & $44.67 \pm 2.33^{\mathrm{b}}$ & $43.5 \pm 3.14^{\mathrm{b}}$ & $9.63^{* * *}$ \\
\hline $\mathrm{NC}$ & $2.52 \pm 0.24^{\mathrm{a}}$ & $1.39 \pm 0.21^{\mathrm{b}}$ & $1.10 \pm 0.10^{\mathrm{b}}$ & $1.34 \pm 0.15^{\mathrm{b}}$ & $9.40^{* * *}$ \\
\hline Ratio & $-0.03 \pm 0.06^{\mathrm{a}}$ & $0.46 \pm 0.06^{\mathrm{b}}$ & $-0.06 \pm 0.02^{\mathrm{a}}$ & $0.62 \pm 0.04^{\mathrm{b}}$ & $34.78^{* * *}$ \\
\hline $\mathrm{D}^{-}$ & $2.07 \pm 0.15^{\mathrm{a}}$ & $0.62 \pm 0.11^{\mathrm{b}}$ & $1.00 \pm 0.04^{\mathrm{b}}$ & $0.71 \pm 0.16^{\mathrm{b}}$ & $23.12^{* * *}$ \\
\hline $\mathrm{D}^{+}$ & $1.96 \pm 0.14^{\mathrm{ab}}$ & $1.87 \pm 0.37^{\mathrm{ab}}$ & $0.88 \pm 0.07^{\mathrm{b}}$ & $2.84 \pm 0.49^{\mathrm{a}}$ & $3.77^{*}$ \\
\hline
\end{tabular}

The plant spatial associations in the community were also significantly influenced by treatment effects (Table 1). Network Connectivity (NC) was significantly higher in C-Grass in comparison with Burnt, Clear-cut and C-Erizón treatments. The ratio of positive to negative associations was significantly larger under C-Erizón and Burnt treatment in comparison with C-Grass or Clear-cut. The density of negative plant associations was significantly larger under C-Grass than under Burnt, C-Erizón and Clear-cut. The density of positive plant association was largest under C-Erizón and the lowest under Clear-cut.

\subsection{Change in plant community structure with time from Burnt and Clear-cut treatments}

Change in plant community structure with time from treatment was analyzed only for Burnt and Clear-cut treatments, as the control C-Erizón and C-Grass were only surveyed one year. Bare soil declined significantly over the time in Burnt $\left(\mathrm{F}_{1,26}=40.08\right.$, $\mathrm{P}<0.001$, slope $=-0.055 \pm 0.01)$ and Clear-cut $\left(\mathrm{F}_{1,8}=52.17, \mathrm{P}<0.001\right.$, slope $=-0.065$ $\pm 0.009)$, with random slope model as the optimal structure of the random component (Fig. 4). Conversely the cover percent of E. horridum increased significantly with time after Burnt $\left(\mathrm{F}_{1,26}=234.21, \mathrm{P}<0.001\right.$, slope $\left.=0.059 \pm 0.01\right)$ and Clear-cut $\left(\mathrm{F}_{1,8}=214.58\right.$, $\mathrm{P}<0.001$, slope $=0.044 \pm 0.003$ ) (Fig. 4). The optimal model was a random intercept model. Evenness showed different results for Burnt and Clear-cut treatment. It declined significantly during the 5-year experiment in the Burnt treatment $\left(\mathrm{F}_{1,26}=38.84, \mathrm{P}<\right.$ 
0.001 , slope $=-0.02 \pm 0.003)$, but no significant changes were observed after Clear-cut $\left(\mathrm{F}_{1,8}=0.04, \mathrm{~ns}\right)$.
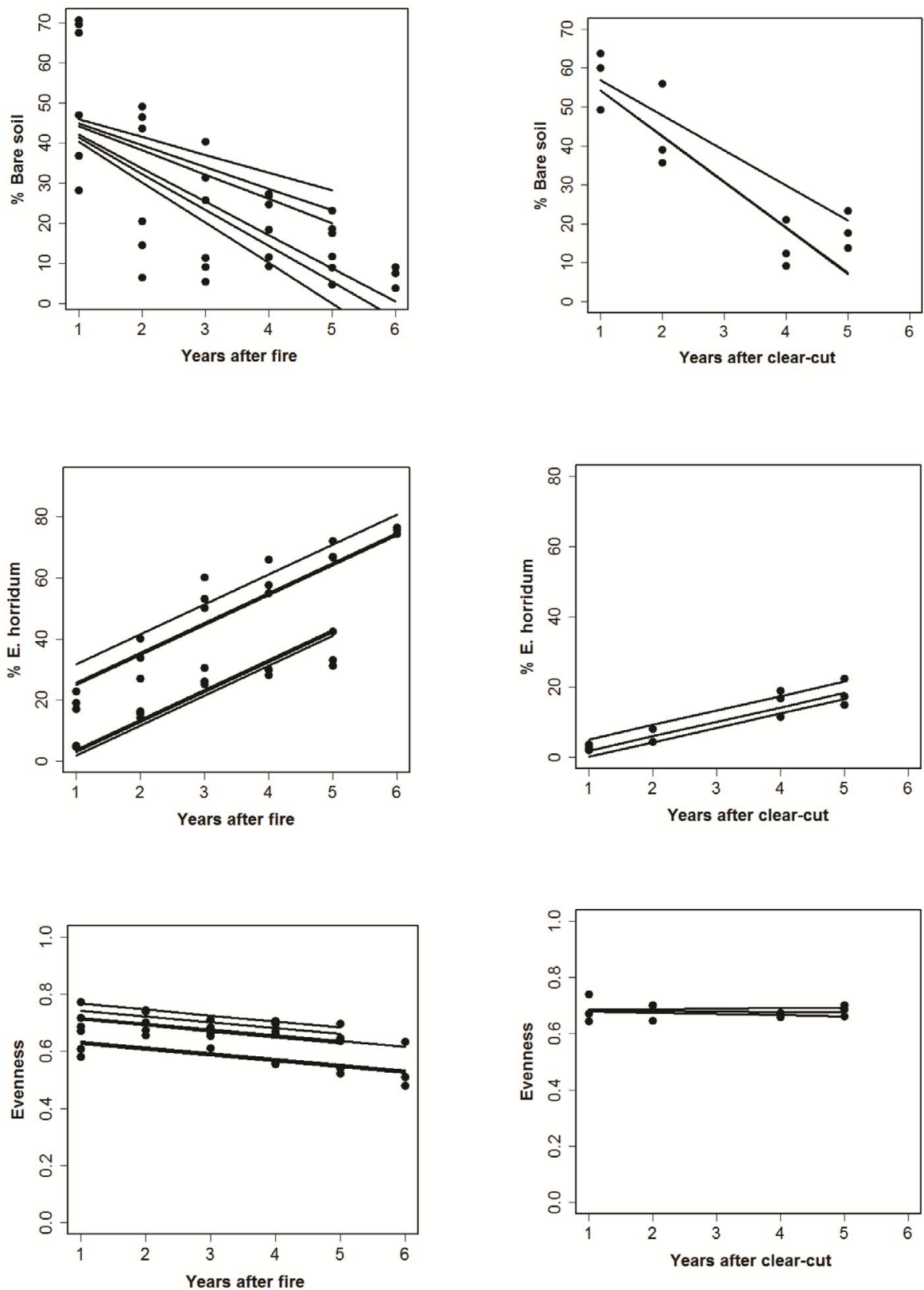

Figure 4. Change in Baresoil, E. horridum cover and Evenness index with time from the Burnt and Clear-cut treatments. The linear mixed model (LMM) included sample site as a random factor. 
Network spatial structure changed with time after Burnt and Clear-cut treatments (Fig. 5). Network Connectivity increased significantly 5 years after Burnt $\left(\mathrm{F}_{1,26}=\right.$ $18.57, \mathrm{P}<0.001$, slope $=0.13 \pm 0.03$ ). A similar trend was observed after Clear-cut, although the difference was not significant $\left(\mathrm{F}_{1,8}=1.36, \mathrm{~ns}\right)$. The density of negative (D) associations increased significantly with time after Clear-cut $\left(\mathrm{F}_{1,8}=3.60, \mathrm{P}=\right.$ 0.09 , slope $=0.17 \pm 0.09)$, but it did not after Burnt $\left(\mathrm{F}_{1,26}=1.53\right.$, ns $)$. Conversely, the ratio of positive to negative association declined significantly with the number of years after Clear-cut $\left(\mathrm{F}_{1,8}=73.48, \mathrm{P}<0.001\right.$, slope $\left.=-0.24 \pm 0.03\right)$, although not effect was observed after Burnt $\left(\mathrm{F}_{1,26}=0.40, \mathrm{~ns}\right)$. Similarly the density of positive associations $\left(\mathrm{D}^{+}\right)$declined significantly with years from Clear-cut $\left(\mathrm{F}_{1,8}=7.10, \mathrm{P}<\right.$ 0.05 , slope $=-0.52 \pm 0.19)$, but no effect was noticed after Burnt $\left(F_{1,26}=0.003, n s\right)$. As the ratio of positive to negative association presented a significant interaction between location and year after Burnt, separated analyses per site were performed, revealing a significant decline in Tella $\left(\mathrm{F}_{1,13}=124.9, \mathrm{P}<0.0001\right.$, slope $\left.=-0.12 \pm 0.01\right)$, but not in Torla $\left(\mathrm{F}_{1,16}=2.01, \mathrm{~ns}\right.$, slope $\left.=0.06 \pm 0.04\right)$.

\subsection{Effects of management treatment on $\mathrm{E}$. horridum sexual reproduction}

Management treatment had a significant effect on E. horridum germination, as revealed by the significant difference between models with and without treatment effects $\left(\chi^{2}=28.46, \mathrm{df}=2, \mathrm{P}<0.001\right)$. E. horridum germination increased drastically after Burnt $(104.34 \pm 10.98, \mathrm{n}=80)$ and Clear-cut $(54.12 \pm 7.19, \mathrm{n}=60)$ treatments in comparison with control (C-Erizón) $(2.27 \pm 0.27, \mathrm{n}=70)$ (Table 2). Tukey's post hoc HSD test showed significant differences in C-Erizón vs. Clear-cut $(\mathrm{z}=18.79, \mathrm{P}<$ 0.001), C-Erizón vs. Burnt $(\mathrm{z}=23.24, \mathrm{P}<0.001)$ and Clear-cut vs. Burnt $(\mathrm{z}=5.23, \mathrm{P}<$ $0.001)$.

The number of germinated seeds declined progressively year after year from the treatment (Table 2). Seedling survival was analyzed only for Burnt and Clearcut treatments, as the number of seeds germinating in C-Erizón, was negligible. The results of the GLMM showed not significant differences between Burnt and Clear-cut treatments $(\mathrm{z}=1.34, \mathrm{P}=0.18$, Tukey's post hoc HSD test $)$, but a significant effect of year of treatment (Table 2). 

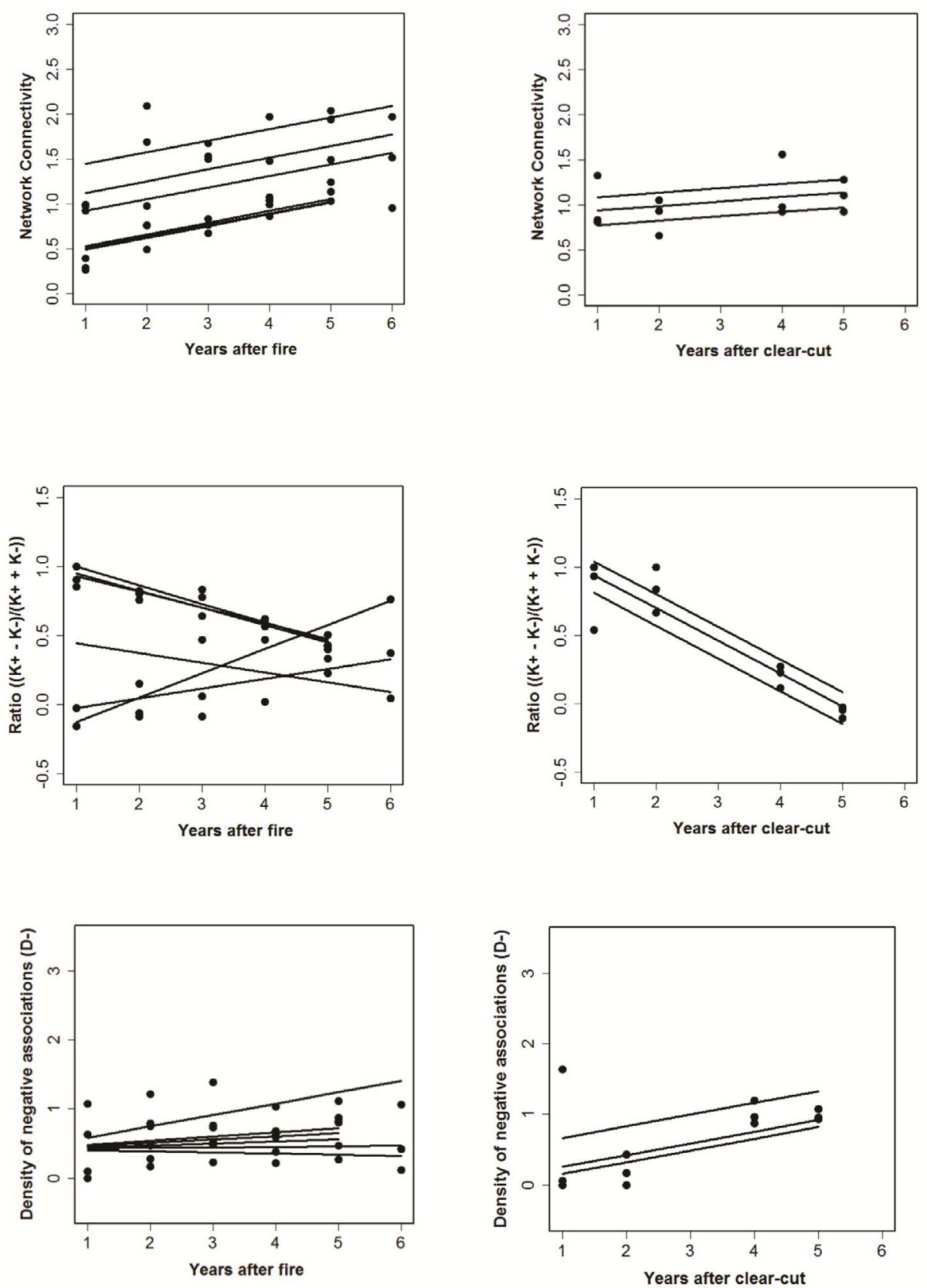

Figure 5. Change in Network Connectivity, ratio of positive to negative associations $\left(K^{+}-K^{-}\right) /\left(K^{+}\right.$ $\left.+K^{-}\right)$, and density of negative association $\left(D^{-}\right)$with time from the Burnt and Clear-cut treatments. The linear mixed model (LMM) included sample site as a random factor. 
Table 2. Results of GLMM analyses for treatment effect (Burnt, Clear-cut and the control $C$-Erizón) on the number of germinated seeds per $\mathrm{m}^{2}$ and yearly survival. The number of years after the treatment was included as repeated factor and plots were nested into location as random effect factor. Only Clear-cut and Burnt treatments were included on the yearly survival effects, as the number of germinated seeds on C-Erizón was negligible. Intercept includes the treatment effect C-Erizón and Yearl for the germination analyses, and Clear-cut and Year 2 for the survival analyses.

\section{Germination}

\begin{tabular}{|l|l|l|l|}
\hline Variable & Estimate & $\mathbf{z - V a l u e}$ & $\mathbf{P}<$ \\
\hline Intercept & 0.339 & 2.09 & 0.04 \\
\hline Clear-cut & 3.786 & 18.79 & 0.001 \\
\hline Burnt & 4.672 & 23.24 & 0.001 \\
\hline Year2 & -0.131 & -5.89 & 0.001 \\
\hline Year3 & -0.387 & -16.14 & 0.001 \\
\hline Year4 & -1.744 & -27.34 & 0.001 \\
\hline Year5 & -1.376 & -25.39 & 0.001 \\
\hline
\end{tabular}

Seedling survival

\begin{tabular}{|l|l|l|l|}
\hline Variable & Estimate & $\mathbf{z}$-Value & $\mathbf{P}$ \\
\hline Intercept & -0.799 & -2.31 & 0.02 \\
\hline Burnt & 0.655 & 1.34 & 0.18 \\
\hline Year3 & 0.544 & 10.47 & $<0.001$ \\
\hline
\end{tabular}

\subsection{Effects of management treatments (Burnt, Clear-cut and C-Erizón) on soil nutrients} after one and four years from the treatment, and comparison with grassland community (C-Grass)

Soil fertility was affected by treatments differently at the first and fourth year after Burnt and Clear-cut treatments in comparison with the control C-Erizón (Table 3). One year after treatment soil OM showed no significant differences between treatments, although $\mathrm{C}$ was significantly lower after Clear-cut, and C-Erizón had the highest $\mathrm{C}$ and $\mathrm{N}$ contents. Four years after the treatment, soil $\mathrm{OM}, \mathrm{C}$ and $\mathrm{N}$ were lower under Burnt than under Clear-cut and C-Erizón treatments (Table 3). No significant differences were observed between Clear-cut and C-Erizón four years after the treatment (Table 3). 
Table 3. Results of the GLMM analyses for treatment effects (Burnt, Clear-cut and Control) on soil nutrients (organic matter $(O M)$, carbon $(\% C)$, nitrogen $(\% N)$ ) and $\mathrm{pH}$ one and four years after the treatment. Plots nested within location were included as random effect factor. The pairwise comparison between treatments was evaluated with Tukey test. Mean \pm se values were back transformed. ${ }^{\bullet}<0.1, * P<0.5$, ** $P<0.01$, *** $P<0.001$.

One year after treatment

\begin{tabular}{|c|c|c|c|c|}
\hline $\begin{array}{l}\text { Variable } \\
\text { response }\end{array}$ & $\begin{array}{c}\text { Burnt } \\
\text { mean } \pm \text { se }\end{array}$ & $\begin{array}{l}\text { Clear-cut } \\
\text { mean } \pm \text { se }\end{array}$ & $\begin{array}{l}\text { C-Erizón } \\
\text { mean } \pm \text { se }\end{array}$ & F2,32 \\
\hline OM & $10.30 \pm 1.09^{\mathrm{a}}$ & $9.85 \pm 1.37^{a}$ & $10.99 \pm 0.86^{\mathrm{a}}$ & 1.41 \\
\hline $\mathrm{C}$ & $7.70 \pm 1.03^{\mathrm{ab}}$ & $6.78 \pm 0.76^{b}$ & $8.64 \pm 0.97^{\mathrm{a}}$ & 4.34 \\
\hline $\mathrm{N}$ & $0.64 \pm 0.08^{\mathrm{ab}}$ & $0.59 \pm 0.06^{\mathrm{b}}$ & $0.73 \pm 0.08^{\mathrm{a}}$ & 3.93 \\
\hline $\mathrm{C} / \mathrm{N}$ & $9.56 \pm 0.26^{\mathrm{a}}$ & $9.61 \pm 0.43^{\mathrm{a}}$ & $9.09 \pm 0.38^{\mathrm{a}}$ & 0.28 \\
\hline $\mathrm{pH}$ & $7.03 \pm 0.14^{\mathrm{a}}$ & $5.78 \pm 0.13^{a}$ & $6.38 \pm 0.27^{\mathrm{a}}$ & 1.51 \\
\hline
\end{tabular}

Four years after treatment

\begin{tabular}{|l|l|l|l|l|}
\hline \multicolumn{1}{|c|}{$\begin{array}{c}\text { Variable } \\
\text { response }\end{array}$} & \multicolumn{1}{|c|}{$\begin{array}{c}\text { Burnt } \\
\text { mean } \pm \text { se }\end{array}$} & $\begin{array}{c}\text { Clear-cut } \\
\text { mean } \pm \text { se }\end{array}$ & $\begin{array}{c}\text { C-Erizón } \\
\text { mean } \pm \text { se }\end{array}$ & \multicolumn{1}{|c|}{ F2,30 } \\
\hline $\mathrm{OM}$ & $7.86 \pm 0.83^{\mathrm{a}}$ & $12.32 \pm 1.45^{\mathrm{b}}$ & $13.39 \pm 2.08^{\mathrm{b}}$ & $11.45^{\bullet}$ \\
\hline $\mathrm{C}$ & $5.63 \pm 0.72^{\mathrm{a}}$ & $10.80 \pm 1.65^{\mathrm{b}}$ & $9.09 \pm 1.13^{\mathrm{b}}$ & 6.03 \\
\hline $\mathrm{N}$ & $0.52 \pm 0.06^{\mathrm{a}}$ & $0.79 \pm 0.10^{\mathrm{b}}$ & $0.75 \pm 0.09^{\mathrm{b}}$ & $9.61^{\bullet}$ \\
\hline $\mathrm{C} / \mathrm{N}$ & $8.94 \pm 0.25^{\mathrm{a}}$ & $9.44 \pm 0.39^{\mathrm{a}}$ & $10.00 \pm 0.36^{\mathrm{a}}$ & 0.72 \\
\hline $\mathrm{pH}$ & $6.40 \pm 0.16^{\mathrm{a}}$ & $5.64 \pm 0.11^{\mathrm{a}}$ & $6.15 \pm 0.21^{\mathrm{a}}$ & 2.12 \\
\hline
\end{tabular}

C-Grass soil fertility values did not show significant differences from those observed on C-Erizón and Clear-cut (11.08 $\pm 0.71 \%$ of OM, $8.15 \pm 0.66 \%$ of C). However, C-Grass showed a high percentage of $\mathrm{N}(0.84 \pm 0.24)$ in comparison with Burnt treatment $(\mathrm{z}=$ $-3.065, \mathrm{P}<0.05)$. Consequently, the $\mathrm{C} / \mathrm{N}$ ratio was significantly lower in $\mathrm{C}$-Grass $(7.84$ $\pm 0.51)\left(\mathrm{F}_{3,42}=5.74, \mathrm{P}<0.01\right)$, while it was similar among the other treatments after the first and fourth year (Table 3). Tukey test $\mathrm{z}$ score for $\mathrm{C} / \mathrm{N}$ ratio showed significant differences between $\mathrm{C}$-Grass and C-Erizón ( $\mathrm{z}=-3.91, \mathrm{P}<0.01$ ), and between $\mathrm{C}$-Grass and Clear-cut $(\mathrm{z}=-3.08, \mathrm{P}<0.05)$, but no significant difference with Burnt treatment $(\mathrm{z}$ $=2.22$, ns).

Soil $\mathrm{pH}$ values were not significantly influenced by treatment effect on the first or fourth year after the treatment (Table 3$)$. pH values in C-Grass $(5.41 \pm 0.13)$ were the lowest. $\mathrm{pH}$ values after Clear-cut were lower than those measured in Burnt and C-Erizón.

\section{Discussion}

Our experiment demonstrated that Clear-cut treatment of E. horridum community was more effective controlling E. horridum colonization than Burnt treatment and contributed to a higher extent to recovering the original grassland vegetation, because 
E. horridum seedling performed worse (lower germination rates) and plant species types were more similar to the original grassland (legumes, non-legumes, and grasses). However, 5 years after applying the Clear-cut, managed pastures still did not reach the conditions of control grasslands (C-Grass). Overall, vegetation recovery after treatment effects was fast after Burnt and Clear-cut, reducing the bare soil cover from $50 \%$ to $20 \%$ after 5 years. E. horridum re-encroachment efficiency depended on the removal mechanism, reaching 50\% cover after Burnt, but only $18 \%$ after Clear-cut.

Mechanical removal is much more effective than fire because these two types of removal differently affect the seed establishment rates of E. horridum on bare soil (Nuche et al., 2018). Fire perturbation increased E. horridum seedling establishment more than clearing as also reported previously (Nuche et al., 2018). Shrubs have been found to increase seedling emergency after burning (De Luis et al., 2005; Rivas et al., 2006). Clear-cut showed less germination success than Burnt, but similar first-year survival rate. The number of germinated seeds declined with time from the treatment in both Clear-cut and Burnt. These results are in concordance with the pyrophytic nature of E. horridum, already reported in the literature (Komac et al., 2013).

Grazing promotes plants with higher nitrogen to carbon ratios, consequently increasing forage quality (Aldezabal et al., 2015). Here we observed an improvement of pasture quality after Clear-cut, with an abundance of grasses and forbs similar to the original grassland (C-Grass). Other studies have also observed an increase of grasses (Krahulec et al., 2001) and legumes (Mayer et al., 2009) abundance with grazing in subalpine zone, as they benefit from grazing by the relief from higher competitors. Furthermore, the selective foraging of palatable species by livestock may favor higher dispersion of palatable species with grazing, increasing the qualitative properties of grazed grasslands (Odriozola et al., 2014). As grazing activity was maintained in our treated study sites, we observed a higher proportion of legumes, non-legume forbs and grasses after Burnt and Clear-cut in comparison with the previous C-Erizón community, which was inaccessible for livestock. However, they did not reach abundances observed in C-Grass. On the other hand, the abundance of woody species and particularly $E$. horridum, was more similar between Burnt and C-Erizón due to the enhancement of $E$. horridum germination after fire events.

Overall, species richness and diversity increased after Burnt and Clear-cut in comparison with C-Erizón, but they were significantly lower than those observed in C-Grass. Burnt and Clear-cut treatments increased diversity relative to C-Erizón, where species richness decreased as typically occurs on shrub dominated communities due to competitive exclusion by shrubs (Price and Morgan, 2008). E horridum removal opened empty spaces that favored the recharge of soil with seeds that arrived by dispersal, resulting in a large soil seed bank after burning and in less extension after the clearing treatment (Nuche et al., 2018), as also occurs with other woody species (Fernandes et $a l ., 2013)$. Plant diversity increases with grazing in ecosystems with long term history of grazing (Milchunas and Lauenroth, 1993), whereas cessation of grazing reduces plant diversity, particularly in mountain grasslands (Krahulec et al., 2001; DeGabriel et al., 2011; Speed et al., 2013). In Central Pyrenees subalpine grasslands also showed higher 
species diversity under grazing activity, although it is reduced in south oriented slopes where E. horridum preferentially colonizes (Komac et al., 2011b). Grazing modifies plant competition directly by reducing dominance of some plant species through consumption (Anderson and Briske, 1995) or indirectly by its effect on soil properties (MedinaRoldán et al., 2012a). In this study, the control grasslands (C-Grass) had the highest diversity and species richness although the differences were only clearly significant with C-Erizón, probably because the replacement of one species by other may mask changes in species diversity. Indeed previous studies reported that, soil seed bank was quite poor in E. horridum, even after its removal (Nuche et al., 2018), and did not reach the level of former grassland vegetation (Bekker et al., 1997; Bossuyt and Honnay, 2008).

Biotic interactions such as interspecific competition and facilitation are known to play an important role in plant communities (Callaway and Walker, 1997; Callaway et al., 2002). In subalpine communities, competition dominates while facilitation is more important as environmental conditions become more extreme (Callaway et al., 2002). In our study, plant associations increased with time after Burnt and Clear-cut treatments. The density of negative associations (a proxy of plant competition) increased over the time, resulting in a decline of spatial aggregation (a proxy of plant facilitation). Spatial aggregation only increased in one of the sites (Torla), probably because the faster expansion rate of E. horridum in Torla (68\% cover after 5 years) than in Tella (35\%) forced plants to co-occur in the gaps left by patches of $E$. horridum clumps, as also occur in C-Erizón. Control grasslands (C-Grass) showed the strongest spatial structure (higher connectivity) mostly characterized by spatial segregation (high $\mathrm{D}^{-}$) and a low ratio of positive to negative association as theory predicts for competitive grasslands (Callaway and Walker, 1997; Callaway et al., 2002). The spatial structure of the plant community became more complex with time from the treatment, with higher connectivity and spatial association density. This was mainly due to the increase of spatial segregation between plants, although aggregation was relevant in the shrub encroached community because of the E. horridum presence. Nevertheless, community spatial structure after 5 years from Burnt and Clear-cut management was still far from the well preserved grassland community (C-Grass).

Prescribed fires and clearing are generally applied to improve soil quality and increase pasture productivity (Collins et al., 1998; Lasanta et al., 2009; Santín and Doerr, 2016). However, the way that management influences soil fertility depends on context situation. In this study we observed that soil fertility was differently affected by treatments at the first and fourth year after Burnt and Clear-cut in comparison with the control C-Erizón. Other studies also found higher soil nutrient contents in grasslands soils than under shrub encroached processes (Nadal-Romero et al., 2018). On year one after treatment, differences between Burnt and Clear-cut were low. However, Burnt significantly reduced soil fertility after the fourth year. Several studies also reported a decrease in soil fertility after prescribed fire events (Martínez-Mena et al., 2001; San Emeterio et al., 2016; Nuche et al.,2018), although other reported neutral or even positive effects on soil nutrients (Fernandes et al., 2013). The effect of fire on soil properties is closely related to the temperature reached during the burning process (Fernandes $e t$ al., 2013; Santín and Doerr, 2016), which mainly affects a shallow layer of soil. For 
example, a prescribed burnt performed on E. horridum community in one of our study areas (Tella), presented the highest temperature $\left(397^{\circ} \mathrm{C}\right)$ at a depth of $1 \mathrm{~cm}$ and declined drastically to $121^{\circ} \mathrm{C}$ at a depth of $2 \mathrm{~cm}$ during the first few minutes after fire (ArmasHerrera et al., 2016). Temperatures above $200^{\circ} \mathrm{C}$ affect chemical soil properties (Santín and Doerr, 2016) and can lead to an important destruction of organic matter in the upper centimeters of the soil after burning (Armas-Herrera et al., 2016). Nevertheless, they are diluted with soil depth as reported by the low variation in soil chemical properties after prescribed fires when analyzed for the top $10 \mathrm{~cm}$ of soil (Alexis et al., 2007; San Emeterio et al., 2016). Soil samples were collected from the upper $15 \mathrm{~cm}$ of the soil in our study and no relevant changes were observed on the first year after burning, although soil fertility declined four years after this treatment, probably due to associated erosion processes. The loss of protective vegetation and the enhancement of water repellency after fire result in increased surface runoff and erosion (Shakesby and Doerr, 2006a; Moody et al., 2013). The erosion rate after a prescribed-fire also depends on other factors, such as slope, rain intensity or vegetation cover. It can vary from non-significant (Zavala et al., 2009) to significant increases (Vega et al., 2005; Fernández et al., 2008, 2012) but it is usually lower than after wildfires events (Soto and Diaz-Fierros, 1998). In our case, the protective effect of the plant debris compensated the loss of vegetation cover after the Clear-cut operation (Fernández et al., 2008, 2012), helping to maintain soil nutrients in Clear-cut areas close to those found in the C-Erizón treatment. Although the enhancement of soil fertility by burning of pastures is one of the main motivations for carrying out prescribed fires (Nigh and Diemont, 2013; Pereira et al., 2015; Santín and Doerr, 2016), post-fire runoff and erosion (Shakesby and Doerr, 2006b; Pereira et al., 2015) may result in loss of soil nutrients in the mid/long term, as it is showed in our study. Increases in soil erosion are greater after prescribed burning than after mechanical removal (Fernández et al., 2008).

Soil pH increased after burning, as it was observed in other studies (Santín and Doerr, 2016), returning to values close to C-Erizón as time progressed from the treatment date. Overall, $\mathrm{pH}$ was the lowest in C-Grass. Furthermore, the $\mathrm{pH}$ value was lower in Clear-cut than in Burnt and C-Erizón.

Grazing induces changes on soil nutrients cycling due to the higher soil microbial activity and $\mathrm{N}$ mineralization, which produce higher quality plant litter (Medina-Roldán et al., 2012b; Niu et al., 2016), resulting in low C/N ratio (Fox et al., 2015). We observed lower values of this ratio in C-Grass than in Clear-cut and C-Erizón, which revealed the higher protein contents of pastures grazed for long time. Grazing in highly productive grasslands, as it is the case of this study, favors species with high nitrogen content (Milchunas and Lauenroth, 1993; Semmartin et al., 2004) which results in lower soil $\mathrm{C} / \mathrm{N}$ ratio in comparison with ungrazed pastures (Speed et al., 2014).

\section{Conclusions}

Our results reveal that although Burnt and Clear-cut treatments may control E. horridum expansion and improve pasture quality in terms of species diversity and species composition, they are not enough to return vegetation to the original well preserved grassland. Clearing is 
a better strategy than burning to recover grasslands colonized by E. horridum, because it is associated to smaller soil degradation and slower recovery of the pyrophyte shrub E. horridum. Nevertheless, intensive grazing after fire or mechanical clearing is recommended (Pittarello et al., 2016) because it accelerates nutrient cycling in temperate and productive grasslands (Frank and Evans, 1997; McNaughton et al., 1997; Bardgett et al., 1998; Semmartin et al., 2004), being the most effective pastoral practice to reverse shrub-encroachment and to increase plant diversity, herbage mass and forage quality.

Given the difficulty to recover shrub encroached grasslands it is recommended to prevent the loss of subalpine grasslands by active management practices addressed to maintain high grazing pressure, particularly in the shrubs advancing border. It is also counseled to prevent the isolation of grassland patches by the establishment of corridors connecting them and favoring the livestock access to those more remote areas. Finally, the use of enclosures to keep animals in less preferred grasslands for some days is also suggested.

\section{Acknowledgements}

This research was funded by Spanish Ministry of Economy, Industry and Competitiveness (CGL2011-27259, CGL-2016-80783-R projects); Spanish National Park organization (DIPA 125/2010 MMAMRM). H. Saiz is supported by the European Research Council (ERC Grant agreement 647038 [BIODESERT]) and Juan de la Cierva-Formación Fellowship (FJCI-2015-26782). We thank the AEMET for providing meteorological information. We especially thank to the Team for the Integral Prevention of Forest Fires (EPRIF, Spanish Ministry of Agriculture, Food and Environment) and P. Sanchez for their field assistance. We thank Miguel Castillo for critically reading and providing helpful suggestions.

\section{References}

Aldezabal, A., Moragues, L., Odriozola, I., Mijangos, I. 2015. Impact of grazing abandonment on plant and soil microbial communities in an Atlantic mountain grassland. Applied Soil Ecology 96, 251-260. https://doi.org/10.1016/j.apsoil.2015.08.013.

Alexis, M., Rasse, D., Rumpel, C., Bardoux, G., Pechot, N., Schmalzer, P., Drake, B., Mariotti, A. 2007. Fire impact on $\mathrm{C}$ and $\mathrm{N}$ losses and charcoal production in a scrub oak ecosystem. Biogeochemistry 82, 201-216. https://doi.org/10.1007/s10533-006-9063-1.

Álvarez-Martínez, J., Gómez-Villar, A., Lasanta, T. 2016. The use of goats grazing to restore pastures invaded by shrubs and avoid desertification: a preliminary case study in the Spanish Cantabrian mountains. Land Degradation \& Development 27, 3-13. https://doi.org/10.1002/ ldr.2230.

Anderson, V.J., Briske, D.D. 1995. Herbivore-induced species replacement in grasslands: is it driven by herbivory tolerance or avoidance? Ecological Applications 5, 1014-1024. https:// doi.org/10.2307/2269351.

André, M.F. 1998. Depopulation, land-use change and landscape transformation in the French Massif Central. Ambio 27, 351-353.

Anthelme, F., Cornillon, L., Brun, J.J. 2002. Secondary succession of Alnus viridis (Chaix) DC. in Vanoise National Park, France: coexistence of sexual and vegetative strategies. Annals of Forest Science 59, 419-428. https://doi.org/10.1051/forest:2002016. 
Armas-Herrera, C.M., Martí, C., Badía, D., Ortiz-Perpiñá, O., Girona-García, A., Porta, J. 2016. Immediate effects of prescribed burning in the Central Pyrenees on the amount and stability of topsoil organic matter. Catena 147, 238-244.https://doi.org/10.1016/j.catena.2016.07.016.

Armas, C., Ordiales, R., Pugnaire, F.I. 2004. Measuring plant interactions: a new comparative index. Ecology 85, 2682-2686. https://doi.org/10.1890/03-0650.

Ayuda, M.I., Pinilla, V. 2002. El proceso de desertización demográfica de la montaña pirenaica en el largo plazo: Aragón. Ager 2,101-138.

Bardgett, R.D., Wardle, D.A., Yeates, G.W. 1998. Linking above-ground and below-ground interactions: how plant responses to foliar herbivory influence soil organisms. Soil Biology and Biochemistry 30, 1867-1878. https://doi.org/10.1016/S0038-0717(98)00069-8.

Bekker, R.M., Verweij, G.L., Smith, R.E. N., Reiné, R., Bakker, J.P., Schneider S. 1997. Soil seed banks in European grasslands: Does land use affect regeneration perspectives? Journal of Applied Ecology 34, 1293-1310. https://doi.org/10.2307/2405239.

Benito Alonso, J.L. 2006. Vegetación del Parque Nacional de Ordesa y Monte Perdido (Sobrarbe, Pirineo Central Aragonés). Publicaciones del Consejo de Protección de la Naturaleza de Aragón, Zaragoza, 425 pp.

Bossuyt, B., Honnay, O. 2008. Can the seed bank be used for ecological restoration? An overview of the seed bank characteristic in European communities. Journal of Vegetation Science 19, 875-884. https://doi.org/10.3170/2008-8-18462.

Callaway, R.M., Brooker, R.W., Choler, P., Kikvidze, Z., Lortie, C.J., Michalet, R., Paolini, L., Pugnaire, F. I., Newingham, B., Aschehoug, E. T., Armas, C., Kikodze, D., Cook, B. J. 2002. Positive interactions among alpine plants increase with stress. Nature 417, 844-848. http:// doi.org/10.1038/nature00812.

Callaway, R.M., Walker, L.R. 1997. Competition and facilitation: a synthetic approach to interactions in plant communities. Ecology 78, 1958-1965. https://doi.org/10.1890/00129658(1997)078[1958:CAFASA]2.0.CO;2.

Canadell, J., López-Soria, L. 1998. Lignotuber reserves support regrowth following clipping of two Mediterranean shrubs. Functional Ecology 12, 31-38. https://doi.org/10.1093/conphys/ cov068.

Canals, R.M., Pedro, J., Rupérez, E., San-Emeterio, L. 2014. Nutrient pulses after prescribedwinter fires and preferential patterns of $\mathrm{N}$ uptakemay contribute to the expansion of Brachypodiumpinnatum (L.) P. Beauv. in highland grasslands. Applied Vegetation Science 17, 419-428. https://doi.org/10.1111/avsc.12088.

Cavieres, L.A., Badano, E.I. 2009. Do facilitative interactions increase species richness at the entire community level? Journal of Ecology 97, 1181-1191. https://doi.org/10.1111/j.13652745.2009.01579.x.

Caviezel, C., Hunziker M., Schaffner, M., Kuhn, N.J. 2014. Soil-vegetation interaction on slopes with bush encroachment in the central Alps- adapting slope stability measurements to shifting process domains. Earth Surface Processes and Landforms 39, 509-521. https://doi. org/10.1002/esp.3513.

Clark, P.E., Lee, J., Ko, K., Nielson, R.M., Johnson, D.E., Ganskopp, D.C.,. Pierson, F.B, Hardegree, S.P. 2016. Prescribed fire effects on resource selection by cattle in mesic sagebrush steppe. Part 2: Mid-summer grazing. Journal of Arid Environments 124, 398-412. https://doi.org/10.1016/j.jaridenv.2015.03.005.

Collins, D., Knapp A.K., Briggs, J.M., Blair, J.M., Steinauer, E.M. 1998. Modulation of diversity by grazing and mowing in native tallgrass prairie. Science 280, 745-747. https://doi. org/10.1126/science.280.5364.745.

Cook, J.G., Hershey, T.J., Irwin, L.L. 1994. Vegetation response to burning on Wyoming mountain-shrub big game ranges. Journal of Rangeland Management 47, 296-302. https://doi.org/10.2307/4002550. 
Cubit, S. 1996. Burning back with the snow: traditional approaches to grassland management in Tasmania. Australian Geographical Studies 34, 216-224. https://doi. org/10.1111/j.1467-8470.1996.tb00117.x.

Chacón-Labella, J., de la Cruz, M., Escudero, A. 2017. Evidence for a stochastic geometry of biodiversity: the effects of species abundance, richness and intraspecific clustering. Journal of Ecology 105, 382-390. https://doi.org/10.1111/1365-2745.12710.

De Luis, M., Raventós, J., González-Hidalgo, J.C. 2005. Factors controlling seedling germination after fire in Mediterranean gorse shrubland. Implication for fire prescription. Journal of Environmental Management, 76, 159-166. https://doi.org/10.1016/j. jenvman.2005.01.014.

DeGabriel, J.L., Albon, S.D., Fielding, D.A., Riach, D.J., Westaway, S., Irvine, R.J. 2011. The presence of sheep leads to increases in plant diversity and reductions in the impact of deer on heather. Journal of Applied Ecology 48, 1269-1277. https://doi.org/10.1111/j.13652664.2011.02032.x.

Fernandes, P.M., Davies, G.M., Ascoli, D., Fernández, C., Moreira, F., Rigolot, E., Stoof, C.R., Vega, J.A. M., Molina, D. 2013. Prescribed burning in southern Europe: developing fire management in a dynamic landscape. Frontier in Ecology and Environment 11, 4-14. https:// doi.org/10.1890/120298.

Fernández-Santos, B.J., Gómez-Gutiérrez, M., Tárrega García-Mares, R. 1992. Efectos de quema, corte, arranque, abonado o pastoreo del matorral de escoba blanca (Cytisus multiflorus) sobre la producción y estructura de la comunidad herbácea. Pastos 22, 131-146.

Fernández, C., Vega, J.A., Fontúrbel, T. 2012. The effects of fuel reduction treatments on runoff, infiltration and erosion in two shrubland areas in the north of Spain. Journal of Environmental Management 105, 96-102. 10.1016/j.jenvman.2012.03.048.

Fernández, C., Vega, J.A., Fontúrbel, T., Jiménez, E., Pérez, J.R. 2008. Immediate effects of prescribed burning, chopping and clearing on runoff, infiltration and erosion in a shrubland area in Galicia (NW Spain). Land Degradation \& Development 19, 502-515. https://doi. org/10.1002/ldr.855.

Fox, H.V., Bonnet, O., Cromsigt, J.P.G.M., Fritz, H., Shrader, A.M. 2015. Legacy effects of different land-use histories interact with current grazing patterns to determine grazing lawn soil properties. Ecosystems 18, 720-733. https://doi.org/10.1007/s10021-015-9857-x.

Frank, D.A., Evans, R.D. 1997. Effects of native grazers on grassland $\mathrm{N}$ cycling in Yellowstone National Park. Ecology 78, 2238-2248. https://doi.org/10.1890/00129658(1997)078[2238:EONGOG]2.0.CO;2.

Gartzia, M., Alados, C.L., Perez-Cabello, F. 2014. Assessment of the effects of biophysical and anthropogenic factors on woody plant encroachment in dense and sparse mountain grasslands based on remote sensing data. Progress in Physical Geography 38, 201-217. https://doi. org/10.1177/0309133314524429.

Gehrig-Fasel, J., Guisan, A., Zimmermann, N.E. 2007. Tree line shifts in the Swiss Alps: Climate change or land abandonment? Journal of Vegetation Science 18, 571-582. https://doi. org/10.1111/j.1654-1103.2007.tb02571.x.

Gellrich, M., Baur P., Koch, B., Zimmermann, N.E. 2007. Agricultural land abandonment and natural forest re-growth in the Swiss mountains: A spatially explicit economic analysis. Agriculture, Ecosystems \& Environment 118, 93-108. https://doi.org/10.1016/j. agee.2006.05.001.

Goodall, D.W. 1952. Some considerations in the use of point quadrats for the analysis of vegetation. Australian Journal of Sciences Research Bulletin 5, 1-41.

Guisan, A., Theurillat, J.P. 2000. Assessing alpine plant vulnerability to climate change: a modeling perspective. Integrated Assessment 1, 307-320. https://doi.org/10.1023/A:1018912114948. 
Heanes, D.L. 1984. Determiation of total organic-C in soils by an improved chromic acid digestion and spectrophotometric procedure. Communications in Soil Science and Plant Analysis 15, 1191-1213. https://doi.org/10.1080/00103628409367551.

Hobbs, N.T., Spowart, R.A. 1984. Effects of prescribed fire on nutrition of mountain sheep and mule deer during winter and spring. Journal of Wildlife Management 48, 551-560. https://doi. $\operatorname{org} / 10.2307 / 3801188$.

Hothorn, T., Bretz, F., Westfall, P. 2008. Simultaneous Inference in General Parametric Models. Biometrical Journal 50, 346-363. https://doi.org/10.1002/bimj.200810425.

Kirkpatrick, J.B., Marsden-Smedley, J.B., Di Folco, M.B., Leonard, S.W.J. 2016. Influence of grazing and vegetation type on post-fire floristic and lifeform composition in Tasmania, Australia. Plant Ecology 217, 57-69. https://doi.org/10.1007/s11258-015-0559-4.

Knapp, A.K., Briggs, J.M., Collins, S.L., Archer, S.R., Bret-Harte, M.S., Ewers, B.E., Peters, D.P., Young, D.R., Shaver, G.R., Pendall, E., Cleary, M.B. 2008. Shrub encroachment in North American grasslands: shifts in growth form dominance rapidly alters control of ecosystem carbon inputs. Global Change Biology 14, 615-623. https://doi.org/10.1111/ j.1365-2486.2007.01512.x.

Komac, B., Alados, C.L., Camarero, J.J. 2011a. Influence of topography on the colonization of subalpine grasslands by Echinospartum horridum. Artic, Antartic and Alpine Research 43, 601-611. https://doi.org/10.1657/1938-4246-43.4.601.

Komac, B., Alados, C.L., Bueno, G., Gómez, D. 2011b. Spatial patterns of species distributions in grazed subalpine grasslands. Plant Ecology 212, 519-529. https://doi.org/10.1007/s11258010-9842-6.

Komac, B., Kefi, S., Nuche, P., Escós, J., Alados, C.L. 2013. Modeling shrub encroachment in subalpine grasslands under different environmental and management scenarios. Journal of Environmental Management 121, 160-169. https://doi.org/10.1016/j.jenvman.2013.01.038.

Körner, C. 2005. The green cover of mountains in a changing environment. In: Huber, U. M., Bugmann, H. K. M., Reasoner, M. A. (Eds.), Global Change and Mountain Regions. Springer, Dordrecht, pp. 367-375.

Körner, C., Paulsen, J. 2004 . A world-wide study of high altitude treeline temperatures. Journal of Biogeography 31, 713-732. https://doi.org/10.1111/j.1365-2699.2003.01043.x.

Krahulec, F., Skálová, H., Herben, T., Hadincová, V., Wildová, R., Pecháčková, S. 2001. Vegetation changes following sheep grazing in abandoned mountain meadows. Applied Vegetation Science 4, 97-102. https://doi.org/10.1111/j.1654-109X.2001.tb00239.x.

Lasanta, T., Arnáez, J., Errea, M.P., Ortigosa, L., Ruiz-Flaño, P. 2009. Mountain pastures, environmental degradation, and landscape remediation: The example of a Mediterranean policy initiative. Applied Geography 29, 308-319. https://doi.org/10.1016/j.apgeog.2008.09.006.

Limb, R.F., Fuhlendorf, S.D., Engle, D.M., Miller, R.F. 2016. Synthesis paper: assessment of research on rangeland fire as a management practice. Rangeland Ecology \& Management 69, 415-422. https://doi.org/10.1016/j.rama.2016.07.013.

MacDonald, D., Crabtree, J.R., Wiesinger, G., Dax, T., Stamou, N., Fleury, P., Lazpita, J.G, Gibon, A. 2000. Agricultural abandonment in mountain areas of Europe: environmental consequences and policy response. Journal of Environmental Management 59, 47-69. https:// doi.org/10.1006/jema.1999.0335.

Martínez-Mena, M., Alvarez, R.J., Castillo, V., Albaladejo, J. 2001. Organic carbon and nitrogen loses influenced by vegetation removal in a semiarid mediterranean soil. Biogeochemistry 61 , 309-321. https://doi.org/10.1023/A:1020257208048.

Mayer, R., Kaufmann, R., Vorhauserc, K., Erschbamer, B. 2009. Effects of grazing exclusion on species composition in high-altitude grasslands of the Central Alps. Basic and Applied Ecology 10, 447-455. https://doi.org/10.1016/j.baae.2008.10.004. 
McNaughton, S.J., Banyikwa, F.F., McNaughton, M.M. 1997. Promotion of the cycling of dietenhancing nutrients by African grazers. Science 278, 1798-1800. https://doi.org/10.1126/ science.278.5344.1798.

Medina-Roldán, E., Paz-Ferreiro, J., Bardgett, R.D. 2012a. Grazing-induced effects on soil properties modify plant competitive interactions in semi-natural mountain grasslands. Oecologia 170, 159-169. https://doi.org/10.1007/s00442-012-2287-y.

Medina-Roldán, E., Paz-Ferreiro, J., Bardgett, R.D. 2012b. Grazing exclusion affects soil and plant communities, but has no impact on soil carbon storage in an upland grassland. Agriculture, Ecosystems \& Environment 149, 118-123. https://doi.org/10.1016/j. agee.2011.12.012.

Melgoza, G., Nowak, R.S., Tausch, R.J. 1990. Soil water exploitation after fire: competition between Bromus tectorum (cheatgrass) and two native species. Oecologia 83, 7-13. https:// www.jstor.org/stable/4219288.

Metzger, M.J., Rounsevell, M.D.A., Acosta-Michlik, L., Leemans, R., Schröter, D. 2006. The vulnerability of ecosystem services to land use change. Agriculture, Ecosystems \& Environment 114, 69-85. https://doi.org/10.1016/j.agee.2005.11.025.

Michalet, R., Schöb, C., Lortie, C.J., Brooker, R.W., Callaway, R.M. 2014. Partitioning net interactions among plants along altitudinal gradients to study community responses to climate change. Functional Ecology 28, 75-86. https://doi.org/10.1111/1365-2435.12136.

Milchunas, D.G., Lauenroth, W.K. 1993. Quantitative effects of grazing on vegetation and soils over a global range of environments. Ecological Monographs 63, 327-366. https://doi. org/10.2307/2937150.

Milchunas, D.G., Sala, O.E., Lauenroth, W.K. 1988. A generalized model of the effect of grazing by large herbivores on grasslands community structure. The American Naturalist 130, 168198. https://www.jstor.org/stable/2461755.

Montserrat, P., Fillat, F. 1990. The system of grassland management in Spain. In: Breymeyer, A. I. (Ed), Managed Grasslands Regional Studies. Elsevier, Amsterdam, pp. 37-70.

Moody, J.A., Shakesby, R.A., Robichaud, P.R., Cannon, S.H., Martin, D.A. 2013. Current research issues related topost-wildfire runoff and erosion processes. Earth-Science Reviews 122, 10 37. https://doi.org/10.1016/j.earscirev.2013.03.004.

Moreira, F., Rego, F.C., Ferreira, P.G. 2001. Temporal (1958-1995) pattern of change in a cultural landscape of northwestern Portugal: implications for fire occurrence. Landscape Ecology 16, 557-567. https://doi.org/10.1023/A:1013130528470.

Moreno-de-las-Heras, M., Diaz-Sierra, R., Turnbull,L., Wainwright, J. 2015. Assessing vegetation structure and ANPP dynamics in a grassland-shrubland Chihuahuan ecotone using NDVIrainfall relationships. Biogeosciences 12, 2907-2925. https://doi.org/10.5194/bg-12-29072015.

Nadal-Romero, E., Otal-Laín, I., Lasanta, T., Sánchez-Navarrete, P., Errea, P., Cammeraat, E. 2018. Woody encroachment and soil carbon stocks in subalpine areas in the Central Spanish Pyrenees. Science of the Total Environment 636, 727-736. https://doi.org/10.1016/j. scitotenv.2018.04.324.

Nigh, R., Diemont, S.A.W. 2013. The Maya milpa: Fire and the legacy of living soil. Frontiers in Ecology and the Environment 11, e45-e54. https://doi.org/10.1890/120344.

Niu, K., He, J.S., Lechowicz, M.J. 2016. Grazing-induced shifts in community functional composition and soil nutrient availability in Tibetan alpine meadows. Journal of Applied Ecology 53, 1554-1564. https://doi.org/10.1111/1365-2664.12727.

Nuche, P., Gartzia, M., Vilellas, J., Reiné, R., Alados, C.L. 2018. Assessment of prescribed fire and cutting as means of controlling the invasion of subalpine grasslands by Echinospartum horridum. Applied Vegetation Science, 21, 198-206. https://doi.org/10.1111/avsc.12354. 
Öckinger, E., Eriksson, A.K., Smith, H.G. 2006. Effects of grassland abandonment, restoration and management on butterflies and vascular plants. Biological Conservation 133, 291-300. https://doi.org/10.1016/j.biocon.2006.06.009.

Odriozola, I., García-Baquero, G.,Laskurain, N.A., Aldezabal, A. 2014. Livestock grazing modifies the effect of environmental factors on soil temperature and water content in a temperate grassland. Geoderma 235-236, 347-354. https://doi.org/10.1016/j.geoderma.2014.08.002.

Olofsson, J., Oksanen, L., Callaghan, T., Hulme, P.E., Oksanen, T., Suominen, O. 2009. Herbivores inhibit climate-driven shrub expansion on the tundra. Global Change Biology 15, 2681-2693. https://doi.org/10.1111/j.1365-2486.2009.01935.x.

Pardo, I., Doak, D.F., García-González, R., Gómez, D., García, M.B. 2015. Long-term response of plant communities to herbivore exclusion at high elevation grasslands. Biodiversity and Conservation 24, 3033-3047. https://doi.org/10.1007/s10531-015-0996-3.

Paula, S., Ojeda, F. 2006. Resistance of three co-ocurring resprouter Erica species to highly frequent disturbance. Plant Ecology 183, 329-336. https://doi.org/10.1007/s11258-005-9043-x.

Paula, S., Pausas, J.G. 2008. Burning seeds: germinative response to heat treatments in relation to resprouting ability. Journal of Ecology 96, 543-552. https://doi.org/10.1111/j.13652745.2008.01359.x.

Pausas, J.G., Keelay, J.E. 2014. Evolutionary ecology of resprouting and seeding in fire-prone ecosystems. New Phytologist 204, 55-65. https://doi.org/10.1111/nph.12921.

Pausas, J.G.,Llovet, J., Rodrigo, A., Vallejo, R. 2008. Are wildfires a disaster in the Mediterranean basin?A review. International Journal of Wildland Fire 17, 713-723. https://doi.org/10.1071/WF07151.

Pereira, P., Jordán, A., Cerdà, A., Martin, D. 2015. Editorial: the role of ash in fire-affected ecosystems. Catena 135, 10-12. https://doi.org/10.1016/j.catena.2014.11.016.

Peringer, A., Siehoff, S., Chételat, J., Spiegelberger, T., Buttler, A., Gillet, F. 2013. Past and future landscape dynamics in pasture-woodlands of the Swiss Jura Mountains under climate change. Ecology and Society 18, 11. http://doi.org/10.5751/ES-05600-180311.

Pinheiro, J., Bates, D., Debroy, S., Sarkar, D., Team, R.C. 2014 . nlme: Linear and nonlinear Mixed Effects Models. R package version 3, 1-117.

Pittarello, M., Probo, M., Lonati, M., Lombardi, G. 2016. Restoration of subalpine srhubencroached grasslands through pastoral practices: effect on vegetation structure and botanical composition. Applied Vegetation Science 19,381-390. https://doi.org/10.1111/avsc.12222.

Post, E., Pedersen, C. 2008. Opposing plant community responses to warming with and without herbivores. Procceeding of the National Academy of Sciences 105, 12353-12358. https://doi. org/10.1073/pnas.0802421105.

Price, J., Morgan, J. 2008. Woody plant encroachment reduces species richness of herb-rich woodlands in southern Australia. Austral Ecology 33, 278-289. https://doi.org/10.1111/ j.1442-9993.2007.01815.x.

Price, M.V., Waser, N.M. 2000. Responses of subalpine meadow vegetation to four years of experimental warming. Ecological Applications 10, 811-823. https://doi. org/10.2307/2641047.

Raffaele, E., Veblen, T.T. 1998. Facilitation by nurse shrubs of resprouting behavior in a postfire shrubland in northern Patagonia, Argentina. Journal of Vegetation Science 9, 693-698. https://doi.org/10.2307/3237287.

Rivas, M., Reyes, O., Casal, M. 2006. Influence of heat and smoke on the germination of six leguminous shrubby species. International Journal of Wildland Fire 15, 73-80. https://doi. org/10.1071/WF05008.

Romano, S. 1995. National parks policy and mountain depopulation: a case study in the Abruzzo Region of the Central Apennines, Italy. Mountain Research and Development 15, 121-132. https://doi.org/10.2307/3673876. 
Saiz, H., Alados, C.L. 2012. Changes in semi-arid plant species associations along a livestock grazing gradient. Plos One 7, e40551. https://doi.org/10.1371/journal.pone.0091478.

Sala, O.E., Chapin, F.S.I., Armesto, J.J., Berlow, E., Blommfield, J., Dirzo, R., Huber-Sanwald, E., Huenneke, L.F., Jackson, R.B., Leemans, R., Lodge, D.M., Mooney, H.A., Oesterheld, M., Poff, N.L., Sykes, M.T., Walker, B.H., Walker, M., Wall, D.H. 2000. Global biodiversity scenarios for the year 2100. Science 287, 1770-1774. https://doi.org/10.1126/ science.287.5459.1770.

San Emeterio, L., Múgica, L., Ugarte, M.D., Goicoa, T., Canals, R.M. 2016. Sustainability of traditional pastoral fires in highlands under global change: Effects on soil function and nutrient cycling. Agriculture, Ecosystems \& Environment 235, 155-163. https://doi.org/10.1016/j.agee.2016.10.009.

Sankaran, M., Hanan, N.P., Scholes, R.J., Ratnam, J., Augustine, D.J., Cade, B.S., Gignoux, J., Higgins, S.I., Le Roux, X., Ludwig, F., Ardo, J., Banyikwa, F., Bronn, A., Bucini, G., Caylor, K.K., Coughenour, M.B., Diouf, A., Ekaya, W., Feral, C.J., February, E.C., Frost, P.G.H., Hiernaux, P., Hrabar, H., Metzger, K.L., Prins, H.H.T., Ringrose, S., Sea, W., Tews, J., Worden, J., Zambatis, N. 2005. Determinants of woody cover in African savannas. Nature 438, 846-849. https://doi.org/10.1038/nature04070.

Santín,C.S., Doerr,H. 2016. Fire effects on soils: the human dimension.Philosophical Transactions of The Royal Society B 371, 20150171. https://doi.org/10.1098/rstb.2015.0171.

Semmartin, M., Aguiar, M.R., Distel, R.A., Moretto, A.S., Ghersa C.M. 2004. Litter quality and nutrient cycling affected by grazing-induced species replacements along a precipitation gradient. Oikos 107, 148-160. http://doi.org/10.1111/j.0030-1299.2004.13153.x.

Shakesby, R.A., Doerr, S.H. 2006a. Wildfire as a hydrological and geomorphological agent. EarthSciences Reviews 74, 269-307. https://doi.org/10.1016/j.earscirev.2005.10.006.

Shakesby, R.A., Doerr, S.H. 2006b. Wildfire as a hydrological and geomorphological agent. Earth-Sciences Reviews 74, 269-307. https://doi.org/10.1016/j.earscirev.2005.10.006.

Shannon, C.E. 1948. A mathematical theory of communication. Bell System Technical Journal 27, 379-423.

Soliveres, S., Maestre, F.T. 2014. Plant-plant interactions, environmental gradients and plant diversity: A global synthesis of community-level studies. Perspectives in Plant Ecology, Evolution and Systematics 16, 154-163. https://doi.org/10.1016/j.ppees.2014.04.001.

Soto, B., Diaz-Fierros, F. 1998. Runoff and soil erosion from areas of burnt scrub: comparison of experimental results with those predicted by the WEPP model. Catena 31, 257-270. https:// doi.org/10.1016/S0341-8162(97)00047-7.

Speed, J.D.M., Austrheim, G., Hester, A.J., Mysterud, A. 2012. Elevational advance of alpine plant communities is buffered by herbivory. Journal of Vegetation Science 23, 617-625. https://doi.org/10.1016/S0341-8162(97)00047-7.

Speed, J.D.M., Austrheim G., Mysterud, A. 2013. The response of plant diversity to grazing varies along an elevational gradient. Journal of Ecology 101, 1225-1236. https://doi. org/10.1111/1365-2745.12133.

Speed, J.D.M., Martinsen, V., Mysterud, A., Mulder, J., Holand, Ø., Austrheim, G. 2014. Longterm Iincrease in aboveground carbon stocks following exclusion of grazers and forest establishment in an Alpine ecosystem. Ecosystems of the World 17, 1138-1150. https://doi. org/10.1007/s10021-014-9784-2.

Tasser, E, Tappeiner, U. 2002. Impact of land use changes on mountain vegetation. Applied Vegetation Science 5, 173-184. https://doi.org/10.1111/j.1654-109X.2002.tb00547.x.

Theurillat, J.P., Guisan, A. 2001. Potential impact of climate change on vegetation in the European Alps: a review. Climatic Change 50, 77-109. https://doi.org/10.1023/A:1010632015572.

Tilman, D., Kareiva, P.M. 1997. Spatial Ecology: The Role of Space in Population Dynamic and Interspecific Interactions. Princeton University Press, NJ, USA. 
Tinner, W., Theurillat, J.P. 2003. Uppermost Limit, Extent, and Fluctuations of the Timberline and Treeline Ecocline in the Swiss Central Alps during the Past 11,500 Years. Arctic, Antarctic, and Alpine Research 35, 158-169.

Tirado, R., Pugnaire, F.I. 2005. Community structure and positive interactions in constraining environments. Oikos 111, 437-444. https://doi.org/10.1111/j.1600-0706.2005.14094.x.

Valiente-Banuet, A., Verdú, M. 2008. Temporal shifts from facilitation to competition occur between closely related taxa. Journal of Ecology $96,489-494$. https://doi.org/10.1111/j.13652745.2008.01357.x.

van der Wal, R. 2006. Do herbivores cause habitat degradation or vegetation state transition? Evidence from the tundra. Oikos 114, 177 - 186. https://doi.org/10.1111/j.2006.00301299.14264.x.

Veen, P., Jefferson, R., de Smith, J., van der Straaten, J. 2009. Grasslands in Europe of high nature value. KNNV Publishing, Zeist (Netherlands), $320 \mathrm{pp}$.

Vega, J.A., Fernández, C., Fontúrbel, T. 2005. Throughfall, runoff and soil erosion after prescribed burning in gorse shrubland in Galicia (NW Spain). Land Degradation \& Development 16, 37-51. https://doi.org/10.1002/ldr.643.

Vilà, M., Lloret, F., Ogheri, E., Terradas, J. 2008. Positive fire-grass feedback in Mediterranean Basin woodlands. Forest Ecology and Management 147, 3-14. https://doi.org/10.1016/ S0378-1127(00)00435-7.

Vittoz, P., Randin, C., Dutoit, A., Bonnet, F., Hegg, O. 2009. Low impact of climate change on subalpine grasslands in the Swiss Northern Alps. Global Change Biology 15, 209-220. https://doi.org/10.1111/j.1365-2486.2008.01707.x.

Vittoz, P., Rulence, B., Largey, T., Freléchoux, F. 2008. Effects of Climate and Land-Use Change on the Establishment and Growth of Cembran Pine (Pinus cembra L.) over the Altitudinal Treeline Ecotone in the Central Swiss Alps. Arctic, Antarctic, and Alpine Research 40, 225 232. https://doi.org/10.1657/1523-0430(06-010)[VITTOZ]2.0.CO;2.

WallisDeVries, M.F., Poschlod, P., Willems, J.H. 2002. Challenges for the conservation of calcareous grasslands in northwestern Europe: integrating the requirements of flora and fauna. Biological Conservation 104, 265-273. https://doi.org/10.1016/S0006-3207(01)00191-4.

Wiegand, T., Huth, A., Getzin, S., Wang, X., Hao, Z., Gunatilleke, C.V.S., Gunatilleke, I.A.U.N. 2012. Testing the independent species' arrangement assertion made by theories of stochastic geometry of biodiversity. Proceedings of the Royal Society B 279, 3312-3320. https://doi. org/10.1098/rspb.2012.0376.

Zavala, L.M., Jordán, A., Gil, J., Bellinfante, N., Pain, C. 2009. Intact ash and charred litter reduces susceptibility to rain splash erosion post-wildfire. Earth Surface Processes and Landforms 34, 1522-1532. https://doi.org/10.1002/esp.1837.

Zuur, A.F., Ieno, E.N., Walker, N.J.K., Saveliev, A.A., Smith, G.M. 2009. Mixed effects models and extensions in Ecology with $R$. Springer, New York. 